\title{
Similitude Conditions Modeling Geosynthetic-Reinforced Piled Embankments Using FEM and FDM Techniques
}

\author{
Keith Jennings and Patrick J. Naughton \\ School of Engineering, Institute of Technology Sligo, Ash Lane, Sligo, Ireland \\ Correspondence should be addressed to Keith Jennings, jennings.keith@itsligo.ie \\ Received 3 January 2012; Accepted 16 February 2012 \\ Academic Editors: N. Lagaros and D. N. Singh
}

Copyright ( $) 2012$ K. Jennings and P. J. Naughton. This is an open access article distributed under the Creative Commons Attribution License, which permits unrestricted use, distribution, and reproduction in any medium, provided the original work is properly cited.

\begin{abstract}
The numerical modelling of geosynthetic-reinforced piled embankments using both the finite element method (FEM) and finite difference method (FDM) are compared. Plaxis 2D (FEM) was utilized to replicate FLAC (FDM) analysis originally presented by Han and Gabr on a unit cell axisymmetric model within a geosynthetic reinforced piled embankment (GRPE). The FEM and FED techniques were found to be in reasonable agreement, in both characteristic trend and absolute value. FEM consistently replicated the FDM outputs for deformational, loading, and load transfer mechanism (soil arching) response within the reinforced piled embankment structure with a reasonable degree of accuracy. However the FDM approach was found to give a slightly higher reinforcement tension and stress concentration but lower reinforcement strain at the pile cap than FEM, which was attributed to the greater discretize of the model geometry in the FDM than in FEM.
\end{abstract}

\section{Introduction}

Special construction methods are required when embankments are constructed on very soft clay or peat. Design of embankments on soft ground raises several concerns such as bearing capacity failure, differential settlements, lateral stresses, and structural instability. Geosynthetic reinforced piled embankments are widely used to overcome these problems when constructing on soft soil.

The geosynthetic-reinforced piled embankment (GRPE) structure consists of closely spaced piles which penetrate the soft soil to reach a stiff bearing substratum, the pile group is overlain by the geosynthetic reinforced, upon which the embankment is constructed, Figure 1. Han and Gabr [1] suggested the benefits associated with reinforced piled embankments are (1) single stage construction without prolonged waiting times; (2) significantly reduced differential settlements; (3) reduced earth pressures; (4) to avoid excavation and refill employed. Pile/column supported embankments improve structural stability and reduce embankment deformations [2-8]. The inclusion of geosynthetic reinforcement just above the pile caps enhances the load transfer efficiency, minimizes yielding of the soil, and reduces total and differential settlements, Han and Gabr [1]; Russell and Pierpoint [9]; Varuso et al. [10]; Rowe and Li, [11]; Bergado and Teerawattanasuk [12]; Briançon and Villard [13]; Li and Rowe [14]; Rowe and Taechakumthorn [15]; Abusharar et al. [16].

The design of reinforced piled embankments is a complex soil-structure interaction problem involving embankment fill, geosynthetic reinforcement, a pile group, and the soft underlying soil see Love and Milligan [17].

In both design and analysis of geosynthetic reinforced piled embankments analytical and numerical techniques are utilized. A number of design methodologies have been proposed for GRPE's BS 8006:1995 [18], EBGEO [19], Carlsson [20], Hewlett and Randolph [21], Russell et al. [22], Svanø et al. [23], and CUR 226 [24]. Numerical techniques have become more common place in the simulation of the structural performance due to improved computing power and more complex soil/material models. Design procedures 


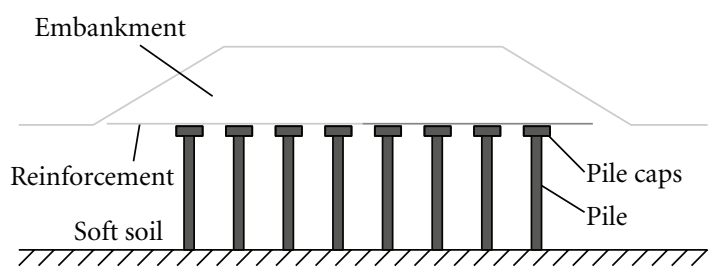

Geosynthetic-reinforced piled embankment

Figure 1: Typical geosynthetic reinforced piled embankment.

based on limit equilibrium methods neglect any aspect of soil and reinforcement deformability; consequently the design approach is not fully satisfactory if the objective is to investigate the time-dependent performance of the structure.

Application of sophisticated numerical modelling techniques improves both the reliability and the economy of engineering design [25]. There are numerous types of numerical methods of simulating a geosynthetic reinforced piled embankments; two of the most common modes of analysis are Finite Element Method (FEM) and the Finite Difference Method (FDM).

In this study Plaxis 2D v9.0 [26] was utilized to model the GRPE problem using an FEM approach. The results of the numerical analysis ware benchmarked against similar analysis reported by Han and Gabr [1] who used FLAC [27] (Fast Lagrangian Analysis of Continua) in an FDM analysis. Plaxis $2 \mathrm{D}$ is a finite element code for $2 \mathrm{D}$ plane strain and axisymmetric modelling of soil and rock behaviour for use on fast personal computers. All models can deal with drained/undrained and nonporous material behaviour. Higher-order 15-noded or 6-noded elements are used to model the geometry. FLAC Version 3.3 is a two-dimensional explicit finite difference program. The two programmes simulate the behaviour of soils, structures built on soil, rock, or other materials that may have undergone plastic flow when their yield limits are reached. The grid can deform in small and large-strain mode and move with the material that is represented. FLAC is able to discretize the model geometry into a greater density of nodes and elements than Plaxis 2D. Plaxis 2D, in order to maintain an advantage of quicker computer processing time than FLAC, limits the discretization of the elements to a maximum of 15 nodes per element.

A geosynthetic reinforced piled embankment is a complex three-dimensional problem; see van Duijnen and Kwast [28]; Laurent et al. [29] and Kempton et al. [4]. Studies by Bergado and Teerawattanasuk [12] concluded that the simulation of a reinforced embankment by $2 \mathrm{D}$ numerical analysis was in good agreement with 3D analyses of the problem. The inclusion of a pile group and the resultant complex pile-soil interaction warrants adopting a $3 \mathrm{D}$ analysis over a simple plain strain or axisymmetric technique. Fahmi Farag [30] concluded that 3D analysis recorded significantly lower tensions and strains in the reinforcement in comparison to 2D FEM analysis of a GRPE.

Satibi [31] suggested plane strain geometry cannot be used to model soil arching, because soil arching instability

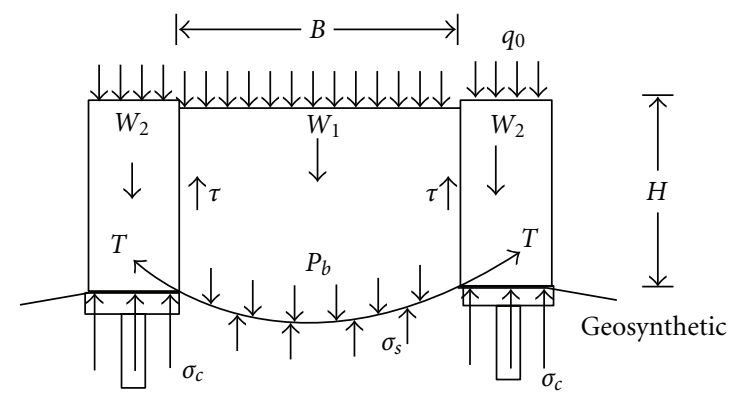

FIGURE 2: Load transfer mechanisms of geosynthetic reinforced pile supported earth platforms (after Han and Gabr [1]).

occurs by punching failure. Slaats [32] found that the results of 2D plane strain and 3D geometry do correspond. Studies by Kempton et al. [4] and Kalla [33] showed that the results of 2D plane strain and 3D geometry have a tendency to be in agreement however the stress reduction ratio was much lower in $3 \mathrm{D}$ analysis compared to $2 \mathrm{D}$ analysis.

Analysis of a 3D geosynthetic reinforced piled embankment structure by 2D finite element analysis and the limits of resultant expressions developed is constrained by the arbitrary restrictions of the 2D models predictive limits.

Plane strain analysis models the cross-section of the GRPE as a homogenous continuum longitudinally. Consideration of pile spacing in the longitudinal direction and its resultant effect on load and stress distribution within the model structure are outside the scope of computation. Plane strain models will produce half tube arching (Kempton et al. [4] and Naughton and Kempton [34]). Expressions may be developed with respect to the trend of deformations, loads, and stresses with the discrepancies of the computed absolute values of the field variables acknowledged.

The geometric idealization of the axisymmetric unit cell model simulation of a single pile within a GRPE is unable to simulate the hemispherical dome shaped due to arching as described by Hewlett and Randolph [21]. The axisymmetric model will produce umbrella arching see Kempton et al. [4] and Naughton and Kempton [34]. A differential in absolute value of the field variable between the idealized model and field data will occur.

In this study, a parametric variation of pertinent factors of influence, embankment height, tensile stiffness of the geosynthetic, and the pile elastic modulus on the performance of the GRPE were investigated. A comparative analysis of Plaxis 2D and FLAC is presented. Expressions are developed with similitude conditions concerning fundamental aspects related to the behaviour of the pile group, the soft soil, and the geosynthetic reinforcement model with the coupled FEM-FDM techniques.

\section{Mechanisms of Load Transfer}

The behaviour of a geosynthetic reinforced pile supported embankments is controlled by the interaction between the piles, the soft foundation soil, embankment fill and the geosynthetic reinforcement, which can be schematically described as shown in Figure 2. 


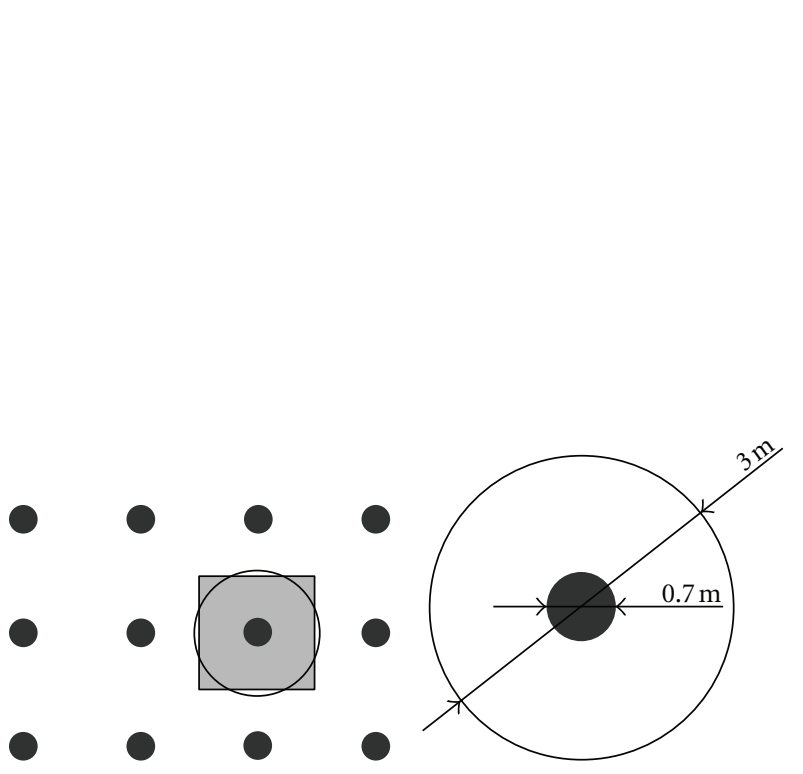

(a) Pile layout

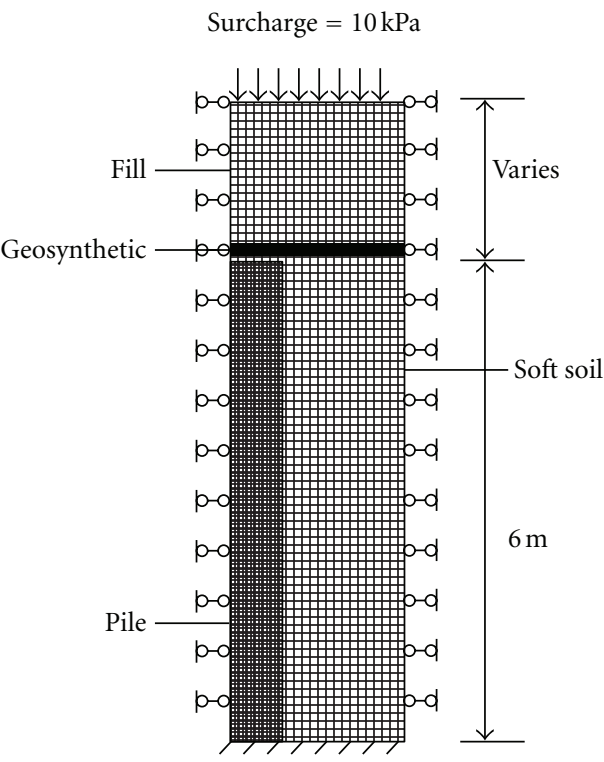

(c) FLAC Model

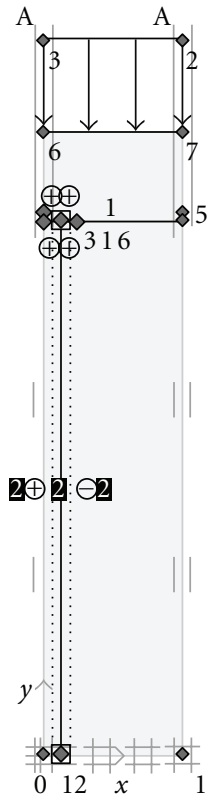

(d) Plaxis 2D Model

Figure 3: Numerical analysis of geosynthetic reinforced piled embankment on soft soil, ((a), (b) and (c) after Han and Gabr [1]).

The embankments fill mass between two adjacent pile caps (Figure 2) has a tendency to move downwards under a combination of the fills self weight $\left(W_{1}\right)$, loading on the embankment surface $\left(q_{o}\right)$, and the presence of soft soil (insufficient bearing capacity) underlying the pile clear span (Figure 2). This movement is partially restrained by shear resistance $\tau$, from the fill directly above the pile caps. The inclusion of geosynthetic reinforcement increases the load transfer to the piles, reduces the shear stresses development in the fill, and ultimately reduces the degree of soil arching; see Han and Gabr [1].

The shear resistance reduces the stress acting on the geosynthetic reinforcement but increases the load acting on the pile caps. This load transfer phenomenon was termed "soil arching effect" by Terzaghi [35]. McNulty [36] proposed that the degree of soil arching can be quantified in the arching ratio:

$$
\rho=\frac{p_{b}}{\gamma H+q_{o}},
$$

where $\rho$ is the soil arching ratio, $p_{b}$ is the applied pressure on geosynthetic, $\gamma$ is the unit weight of embankment fill, $H$ is the height of embankment and $q_{o}$ is the uniform surcharge on embankment surface. The magnitude of the soil arching ratio ranges between 0 and 1. Complete arching is defined as $100 \%$ when $\rho$ tends to zero. However, no soil arching is represented when $\rho$ tends to unity.

Han and Wayne [37] suggested that the degree of the load transfer due to the soil arching effect can also be quantified using the stress concentration ratio $(n)$, defined as the stress on the pile caps $\left(\sigma_{c}\right)$ to the stress imparted on the soft soil layer $\left(\sigma_{s}\right)$ under the geosynthetic reinforcement, $n=\sigma_{c} / \sigma_{s}$. A high stress concentration $(n)$ corresponds with a high degree of soil arching within the structure. The stress concentration increases for an increase in embankment height and the inclusion of reinforcement in the structure.

The mechanisms of load transfer within the geosynthetic reinforced piled embankment on soft soil are greatly influenced by the degree of soil arching, the reinforcement stiffness, and the stress concentration due to the stiffness differential gradient between the pile and soft soil.

\section{Numerical Modeling}

Plaxis 2D was used to reproduce the analysis of GRPEs originally presented by Han and Gabr [1]. The Plaxis 2D axisymmetric model was used to simulate a single-cell pile arranged in a typical square pattern (Figure 3(a)). As a simplifying assumption, each pile was considered as having its own zone of influence within a radius equal to half the pile spacing from the centreline of the pile, (Figure $3(\mathrm{~b})$ ). This approach was consistent with the Han and Gabr [1] study. The geometry of the GRPEs was the same as that originally selected by Han and Gabr [1] and consisted of $3.0 \mathrm{~m}$ pile spacing, $0.7 \mathrm{~m}$ pile diameter, $6.0 \mathrm{~m}$ depth of soft soil, and a $3.0 \mathrm{~m}$ embankment height (Figures 3(a), 3(b), and 3(c)). A $10 \mathrm{kN} / \mathrm{m}^{2}$ surcharge loading represented trafficked load on the embankment surface. The selected geometry is typical of that used in practice.

Han and Gabr [1] utilized a nonlinear hyperbolic elastic model developed by Duncan and Chang [38] for both the embankment fill and the foundation soil that enabled the stress-dependent nature of the soil to be simulated (Table 2). The Duncan-Chang model is an incremental nonlinear stress-dependant model which is also known as 


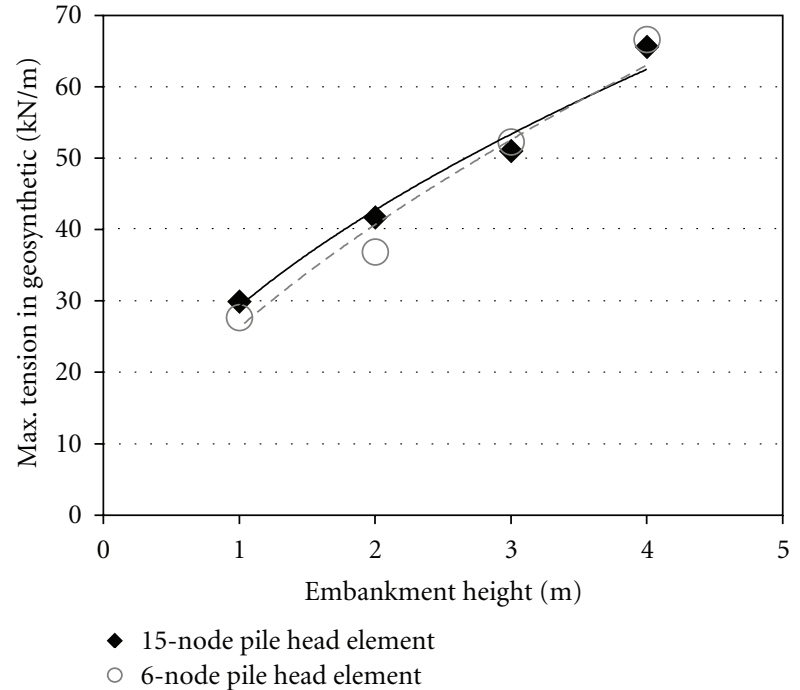

(a)

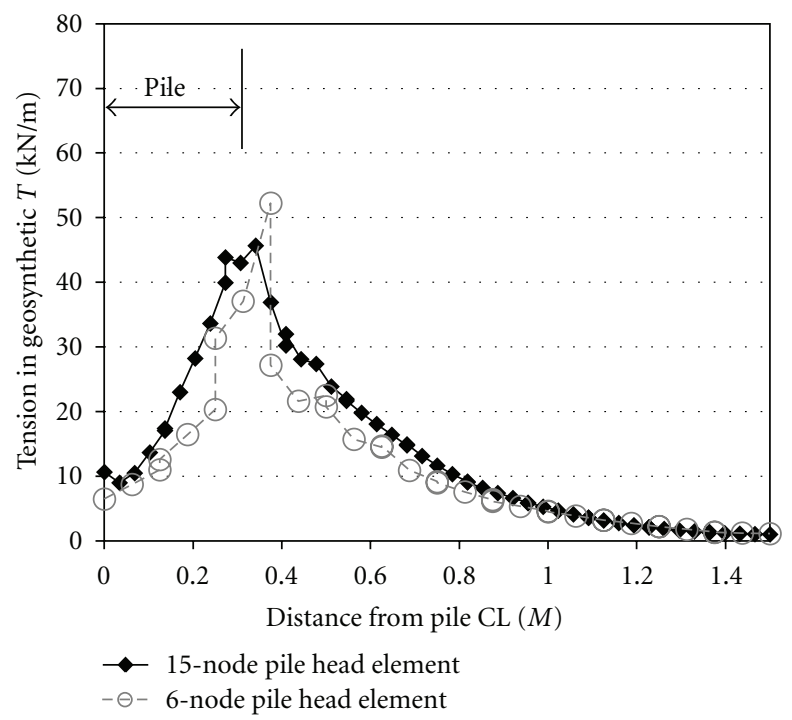

(b)

FIgURE 4: Influence of 6- and 15-node elements in Plaxis 2D on (a) Maximum tension in geosynthetic (b) tension distribution in geosynthetic.

the hyperbolic model; see Duncan and Chang, [38]. This model is based on stress-strain curve in drained triaxial compression test of both clay and sand which can be approximated by a hyperbola with a high degree of accuracy. Its failure criteria is based on Mohr-Coulomb's two strength parameters; this model describes the three important characteristics of soil, namely, nonlinearity, stress-dependant and inelastic behaviour of cohesive and cohesionless soil. It is an enhancement of the Mohr-Coulomb model.

The constitutive models used in the present study differed slightly from that original used by Han and Gabr [1]. The Hardening Soil Model (HSM), a standard model in Plaxis 2D [26], was used for the foundation soil and a Mohr Coulomb model for the embankment fill (Table 1).

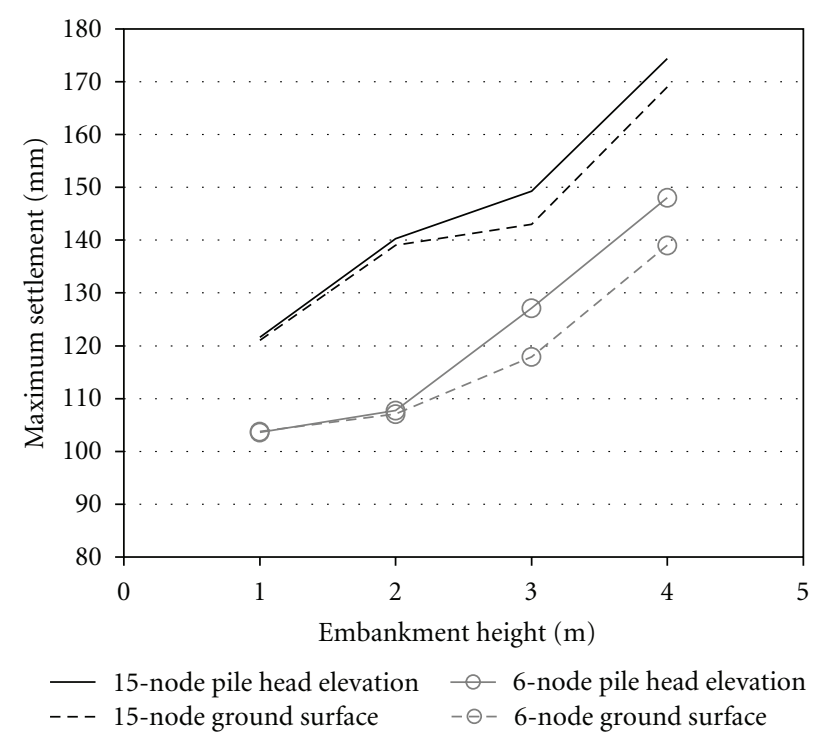

FIGURE 5: Maximum settlement in geosynthetic based on 6- and 15node element densities in Plaxis 2D.

TABle 1: Parameters for Plaxis 2D generic model case.

\begin{tabular}{ll}
\hline Material & Parameter \\
\hline \multirow{3}{*}{ Foundation Soil } & $E_{50}^{\text {ref }}=1.33 \mathrm{MPa}, E_{\text {oed }}^{\text {ref }}=1.33 \mathrm{MPa}$, \\
& $\psi=0.0^{\circ}, \gamma_{\text {unsat }}=15 \mathrm{kN} / \mathrm{m}^{3}, \gamma_{\text {sat }}=18 \mathrm{kN} / \mathrm{m}^{3}$, \\
& $m=1.0, K_{o}^{\mathrm{nc}}=0.625$ \\
\hline Embankment Fill & $E=2000, v=0.3, c=0.0 \mathrm{kPa}, \varphi=30.0^{\circ}$, \\
& $\psi=0.0^{\circ}, \gamma_{\text {unsat }}=18 \mathrm{kN} / \mathrm{m}^{3}, \gamma_{\text {sat }}=18 \mathrm{kN} / \mathrm{m}^{3}$ \\
\hline Pile & $E=30 \mathrm{GPa}, \mu=0.2$ \\
\hline Geosynthetic & $J=860 \mathrm{kN} / \mathrm{m}$ \\
\hline
\end{tabular}

The main advantage of the hardening soil model is its ability to consider the stress path and its effect on the soil stiffness and its behaviour.

The hardening soil (HS) model is derived from the hyperbolic model of Duncan and Chang [38], with some improvement on the hyperbolic formulations in an elastoplastic framework; see Schanz et al. [39]. The Hardening Soil model is a true second-order model for soils in general, Brinkgreve and Vermeer [40]. The model involves friction hardening to model the plastic shear strain in deviatoric loading and cap hardening to model the plastic volumetric strain in primary compression. Like the nonlinear hyperbolic elastic Duncan and Chang [38] failure is defined by means of Mohr-Coulomb failure criterion. The HS model is in good agreement with the Duncan-Chang model regarding its hyperbolic stress-strain response when simulating a standard drained triaxial test; see Ti et al. [41].

A Mohr Coulomb (MC) model was selected for the embankment fill in this study. The primary disadvantage of a MC model is that it only gives a first-order approximation of deformations. However, the MC model is used extensively, 
TAble 2: Parameters for Han and Gabr [1] FLAC generic model case.

\begin{tabular}{ll}
\hline Material & Parameter \\
\hline \multirow{2}{*}{ Foundation soil } & $\begin{array}{l}K=50, R_{f}=0.7, \mu=0.3, m=0.45, \varphi=22^{\circ}, \\
c=0 \mathrm{kPa}, H=3.0 \mathrm{~m}\end{array}$ \\
\hline \multirow{2}{*}{ Embankment fill } & $\begin{array}{l}K=150, R_{f}=0.7, \mu=0.3, m=0.25, \varphi= \\
30^{\circ}, c=0 \mathrm{kPa}, H=3.0 \mathrm{~m}\end{array}$ \\
\hline Pile & $E_{p}=30 \mathrm{GPa}, \mu=0.2$ \\
\hline Geosynthetic & $J=E_{g} \times t=860 \mathrm{kN} / \mathrm{m}, \mu=0.45$ \\
\hline
\end{tabular}

primarily as the required parameters can be readily determined.

The foundation soil was underlain by a very stiff layer. It was assumed that no deformation occurred below the soft foundation soil and at the vertical extremities of the model (Figures 3(c) and 3(d)). Plaxis 2D modeled the pile element as a plate model with a linear elastic material set applied, Table 1 and Figure 3(d).

A parametric study in Plaxis 2D using both 6- and 15node elements (greatest density of nodes possible) indicated that the tension in the geosynthetic (Figure 4), was in close agreement for both node densities. However, the maximum settlement, (Figure 5) predicted using the 15-node elements was approximately $20 \%$ higher than that given by the 6 -node elements. For this reason the 15-node elements were used for all analysis in this study.

For simplicity, one single layer of geosynthetic reinforcement was included in the embankment structure. The geogrid was represented by a geotextile element in Plaxis (Table 1), which are flexible elastic elements that represent a sheet of fabric in out of plane direction. FLAC modeled the pile and geosynthetic as linear elastic materials (Table 2). To simplify the problem, no geosynthetic creep factor has been considered, which is also consistent with Han and Gabr [1].

Han and Gabr [1] suggested that the interface behaviours of geosynthetic soil and pile soil are important for the performance of the geosynthetic reinforced piled embankment. Under relatively small deformations, however, the influences of the behaviour at the material interfaces are expected to be negligible. In the Han and Gabr [1] study, the interfaces between the piles, soil, and geosynthetic reinforcement are assumed to be fully bonded. To replicate the interface conditions of the FLAC analyses, Plaxis 2D modeled the interfaces full bonded $\left(R_{\text {inter }}=1.0\right)$.

\section{Analysis of Results}

The results and comparison of the analysis are presented with the FDM and FEM techniques referred to as FLAC and Plaxis $2 \mathrm{D}$, respectively.

4.1. Maximum Settlement. The maximum settlements were recorded at two principal locations within the model. The first was at the pile head elevation midspan between two adjacent piles. The second was situated at the top of the embankment immediately above the first point. As expected,

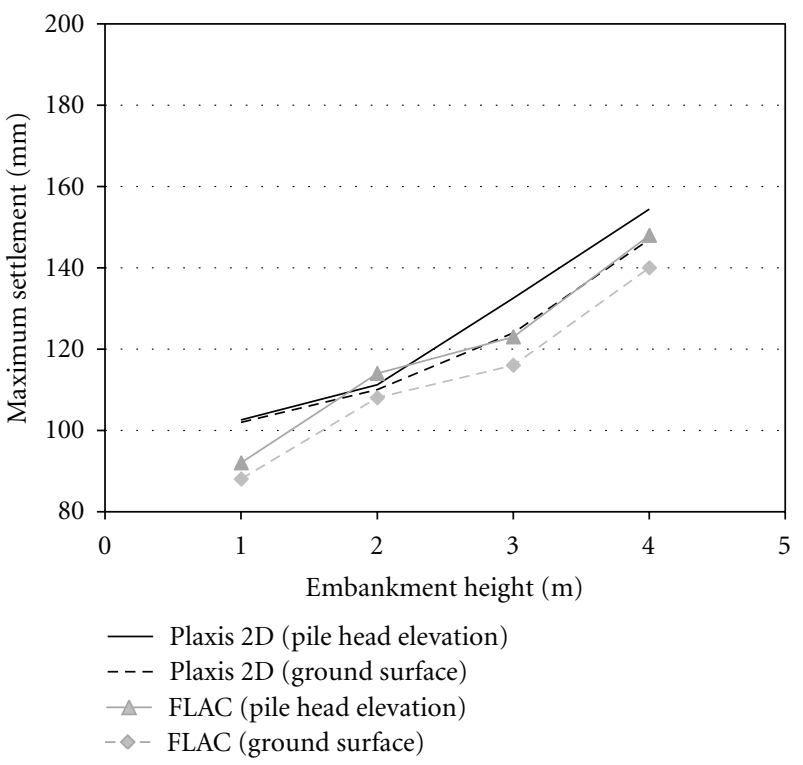

FIGURE 6: Influence of embankment height (reinforced) on maximum settlements.

the maximum deformation occurred at the first location, midspan between the piles at the base of the embankment.

The magnitude of the deformational response of the embankment increased for an increase in the embankment height (Figure 6). The maximum settlement of the embankment fill was slightly higher in Plaxis $2 \mathrm{D}$ than FLAC but the settlement was always within 12\% of each other (Figures 6 and 7). For a relatively low embankment height the maximum settlements of the FLAC model increased at a greater rate than the Plaxis model (Figures 6 and 7). For embankment heights greater than $3.0 \mathrm{~m}$, the rate of increase in settlements (at both measurement locations) occurred at the same rate. For the unreinforced case (Figure 7), Plaxis 2D recorded a greater difference in the maximum deformation (Plaxis versus FLAC) at low embankment heights in comparison to the reinforced case (Figure 6).

The maximum settlements at both measurement locations decreased for an increase in the geosynthetic reinforcement stiffness (Figure 8). The inclusion of geosynthetic reinforcement, with a stiffness of $860 \mathrm{kN} / \mathrm{m}$, over the piles resulted in a significant reduction in the settlements at both measurement locations in both Plaxis 2D and FLAC; increasing the stiffness of the reinforcement did not significanatly change the maximum settlement in either numerical code (Figure 8). Both Plaxis 2D and FLAC were in good agreement on the influence of geosynthetic reinforcement stiffness on the maximum settlements, differing only in cases with a stiffness greater than $4,000 \mathrm{kN} / \mathrm{m}$. The maximum settlements decreased slightly for an increase in stiffness up to $4,000 \mathrm{kN} / \mathrm{m}$. The FLAC analysis suggested that the influence of the reinforcement became less important when the geosynthetic reinforcement stiffness exceeds $4,000 \mathrm{kN} / \mathrm{m}$. however, Plaxis $2 \mathrm{D}$ yielded an approximate $6 \%$ reduction in settlement for stiffnesses greater than $4,000 \mathrm{kN} / \mathrm{m}$ (stiffness increased to $9000 \mathrm{kN} / \mathrm{m}$ ) (Figure 8). 


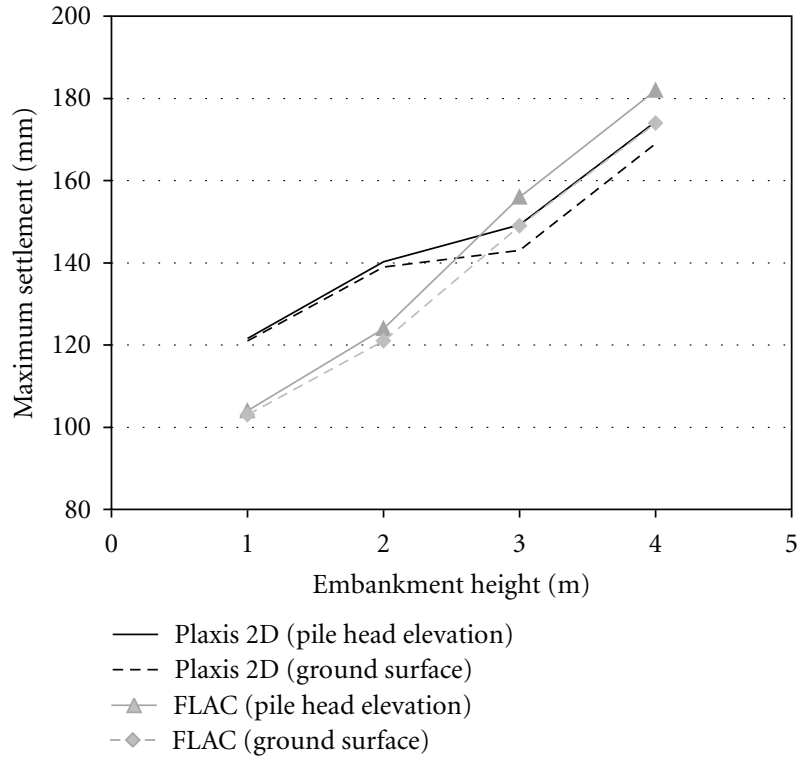

Figure 7: Influence of embankment height (unreinforced) on maximum settlements.

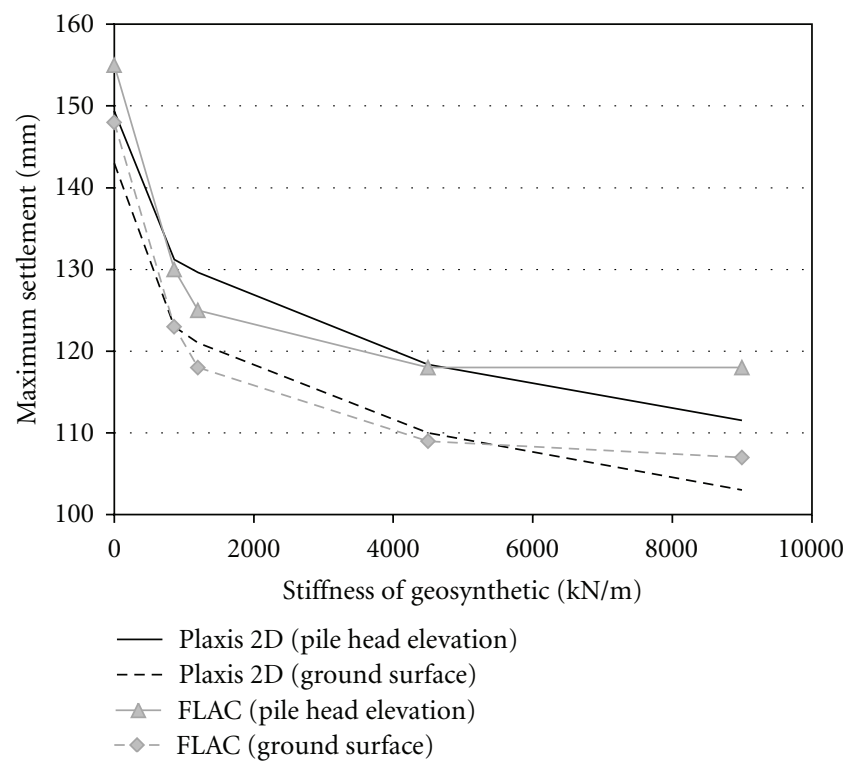

Figure 8: Influence of geosynthetic reinforcement stiffness on maximum settlements.

The pile elastic modulus had a pronounced effect on the maximum settlements recorded during the numerical analysis. Maximum settlements decreased for an increase in pile modulus, for both reinforced and unreinforced cases at both settlement monitored locations (Figures 9 and 10).

The maximum settlement was a function of the ratio of the pile elastic modulus to the soft soil elastic modulus; the greater the pile elastic modulus is, the greater the differential stiffness of the pile/soft soil stiffness became. An increase in the pile elastic modulus therefore increased the stiffness offered by the pile/soft soil and ultimately resulted in lower maximum settlements for a greater pile elastic modulus (Figures 9 and 10).

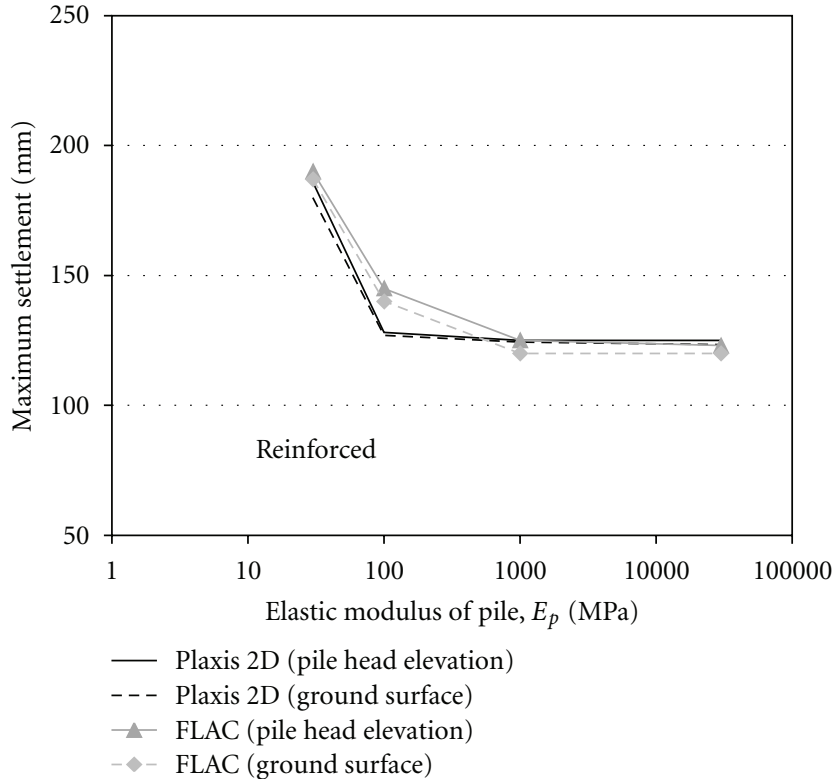

FIGURE 9: Influence of pile elastic modulus on maximum settlements.

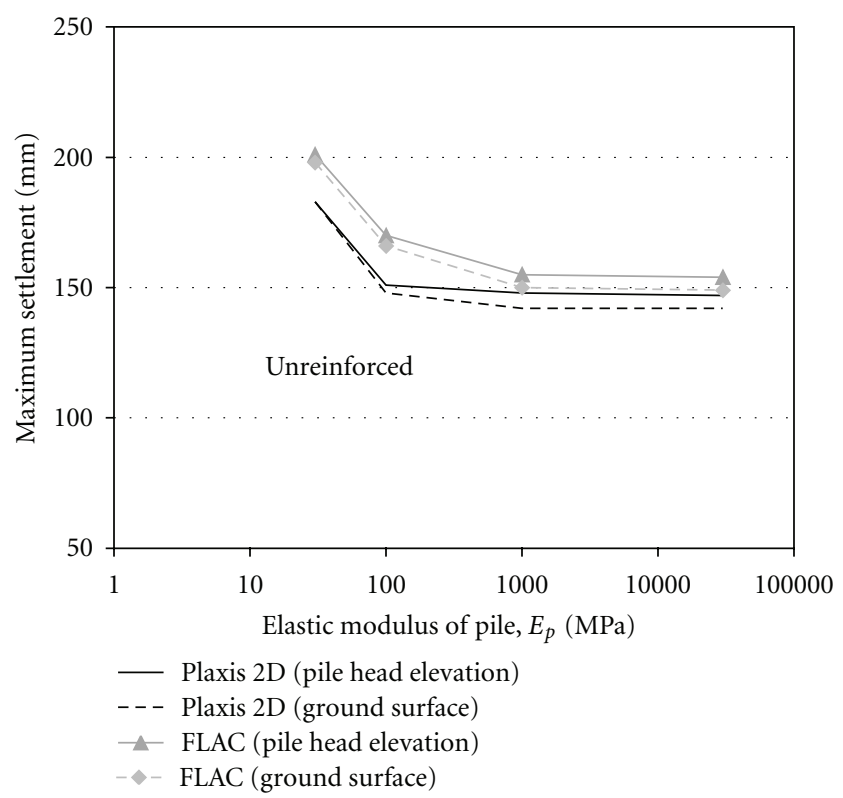

FIGURE 10: Influence of pile elastic modulus on maximum settlements.

Plaxis 2D and FLAC both produced similar responses as the pile elastic modulus was varied between an initial value of $30 \mathrm{MPa}$ and $1000 \mathrm{MPa}$. Increasing the elastic modulus from $30 \mathrm{MPa}$ to $100 \mathrm{MPa}$ produced the greatest reduction in the maximum settlements. Both Plaxis $2 \mathrm{D}$ and FLAC suggested that a pile elastic modulus greater than $1 \mathrm{GPa}$ had an insignificant effect on the magnitude of maximum settlements at both measurement locations for both reinforced and unreinforced cases (Figures 9 and 10).

For the unreinforced case Plaxis 2D yielded a greater rate of reduction and lower overall magnitudes of maximum settlements than FLAC (Figure 10). Elastic pile moduli greater 
than $100 \mathrm{MPa}$ (Plaxis 2D, Figure 10) yielded only a small reduction in the magnitude of the maximum settlements.

4.2. Differential Settlements. Differential settlements were defined as the difference in settlement between the top of the pile cap and midspan between two adjacent pies at the base of the embankment. The differential settlements were monitored at two locations on the pile embankment model: the first was at the embankment surface and the second, at the pile head elevation.

The differential settlements from Plaxis 2D and FLAC were in relatively good agreement, Figure 11. The absolute magnitudes and the characteristic trend of the differential settlements were within $5 \%$ of their corresponding values. The most significant difference between Plaxis 2D and FLAC occurred at the lowest embankment height of $1.0 \mathrm{~m}$ (Figure 11).

In the unreinforced case Plaxis $2 \mathrm{D}$ and FLAC produced similar differential settlements at the embankment surface, Figure 12. However, in Plaxis 2D the differential settlements at the pile head did diverge from the FLAC values as the embankment height increased, Figure 12.

Differential settlements reduced for an increase in geosynthetic reinforcement stiffness (Figure 13). Plaxis 2D always recorded lower magnitudes of differential settlements than FLAC (Figure 13). However, Plaxis and FLAC gave a similar trend; with the greatest reduction in differential settlement (Plaxis 2D 14.5\% and FLAC 16.2\%) occurring after initial inclusion of geosynthetic reinforcement (Figure 13). FLAC suggested that a geosynthetic stiffness greater than $4,000 \mathrm{kN} / \mathrm{m}$ has no affect on the magnitude of differential settlements (Figure 13), which was consist with the maximum settlement reported in (Figure 8). In contrast, a geosynthetic stiffness greater than $4,000 \mathrm{kN} / \mathrm{m}$ in Plaxis $2 \mathrm{D}$ yielded a further slight reduction in the magnitude of differential settlements (Figure 13).

An increase in the elastic pile modulus increased the differential settlements within the structure in both Plaxis $2 \mathrm{D}$ and FLAC (Figures 14 and 15). Both recorded the greatest increase in differential settlement for an increase in elastic pile modulus from $30 \mathrm{MPa}$ to $100 \mathrm{MPa}$. Both Plaxis and FLAC suggest that differential settlements plateaued for an increase in elastic pile modulus greater than $1000 \mathrm{MPa}$ (Figures 14 and 15). At the pile head elevation for both the reinforced (Figure 14) and unreinforced cases (Figure 15), an increase in the elastic modulus resulted in a convergence in the magnitude of the differential settlement predicted by Plaxis 2D and FLAC. The differential settlement recorded by Plaxis 2D at the embankment surface for the reinforcement cases remained constant for a range of pile elastic stiffness (Figures 14 and 15), while FLAC reported a significant increase in differential settlement.

4.3. Vertical Stresses above and below Geosynthetic. The inclusion of geosynthetic reinforcement had a significant influence on the vertical stress distribution above and below the geosynthetic reinforcement layer. Inclusion of geosynthetic reinforcement dramatically affected the soil

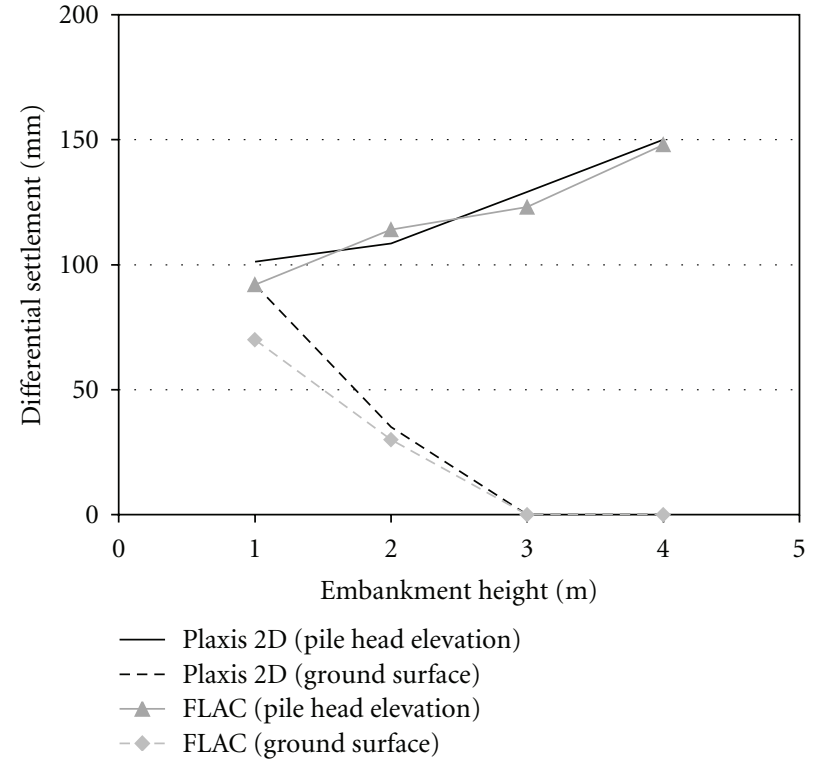

FIGURE 11: Influence of embankment height (reinforced) on differential settlements.

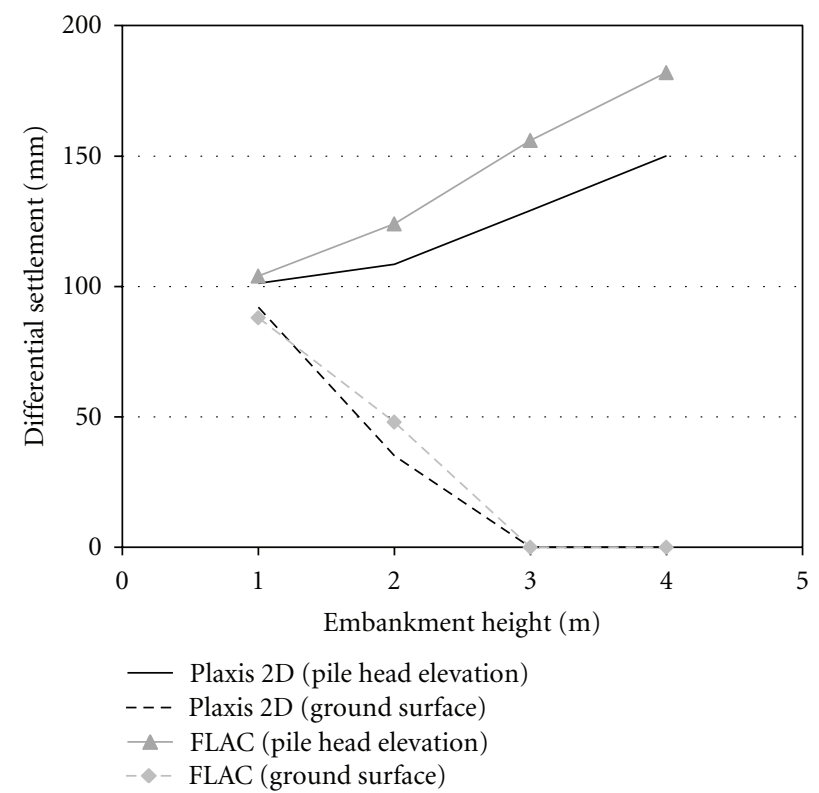

FIGURE 12: Influence of embankment height (unreinforced) on differential settlements.

arching conditions and load transfer mechanisms within the embankment fill. Figures 16 and 17 illustrate that for both reinforcement and unreinforced cases the greatest concentration of vertical stresses occurred at the pile cap head in both Plaxis 2D and FLAC.

Cognitive capacity of the arching conditions has been greatly aided by past studies such as Hewlett and Randolph [21] and McNulty [36]. The development of a hemispherical arch over the pile clear span transferring loading onto the pile caps corresponds to an increase in stress concentration at the pile caps. Figure 16 (below geosynthetic) illustrates the presence of arching within the structure, and the vertical 


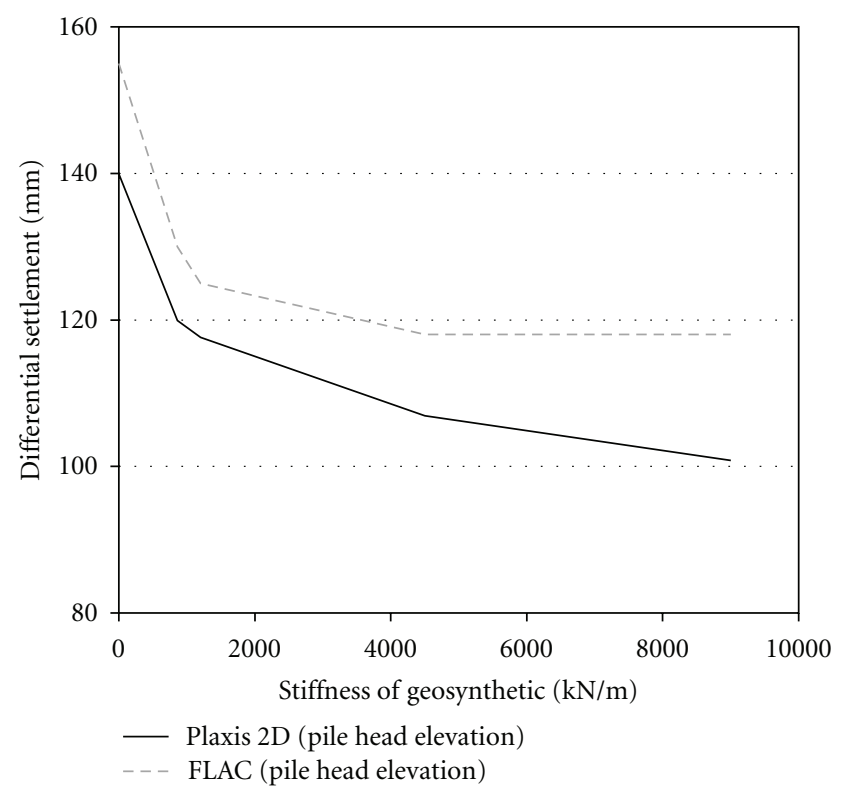

FIGURE 13: Influence of geosynthetic reinforcement stiffness on differential settlements.

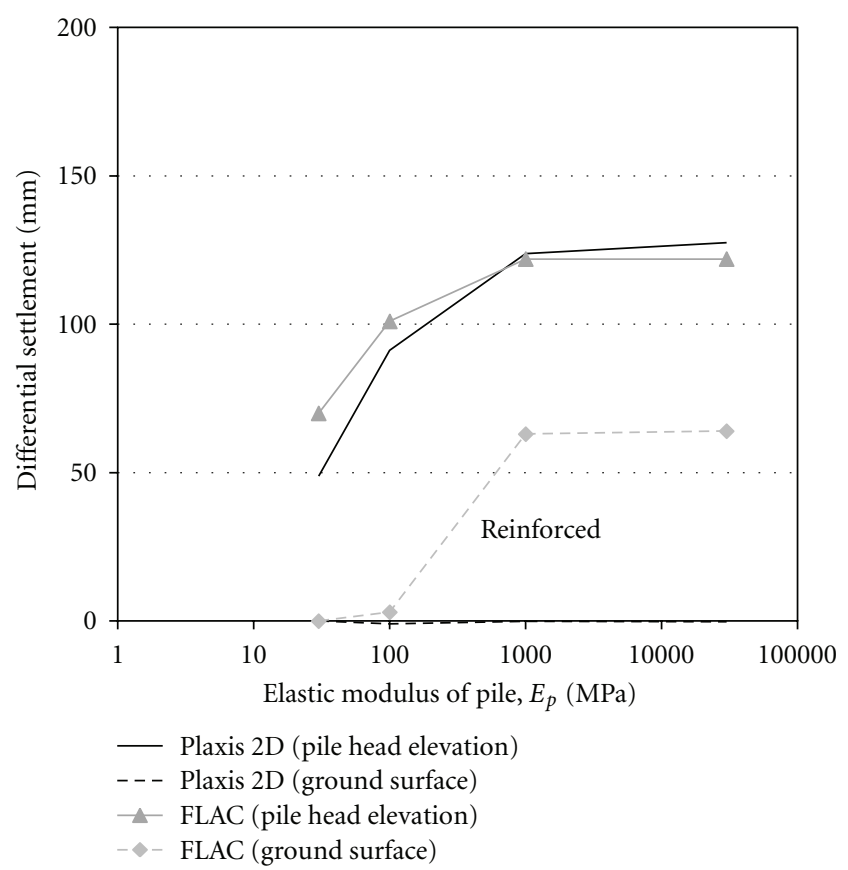

FIGURE 14: Influence of embankment height on differential settlements (reinforced case).

stress peak near the outer edge of the pile corresponded with the occurrence of both soil arching and the transfer of load from the geosynthetic reinforcement.

The vertical stress acting above and below the geosynthetic reinforcement was extrapolated from Plaxis 2D utilizing the cross-section tool. This tool intercepts elements within the deformed discretized mesh and the field values (vertical stresses) at the intercepts. The extrapolation of values from the model with an insufficiently dense discretized mesh may be a possible source of error.

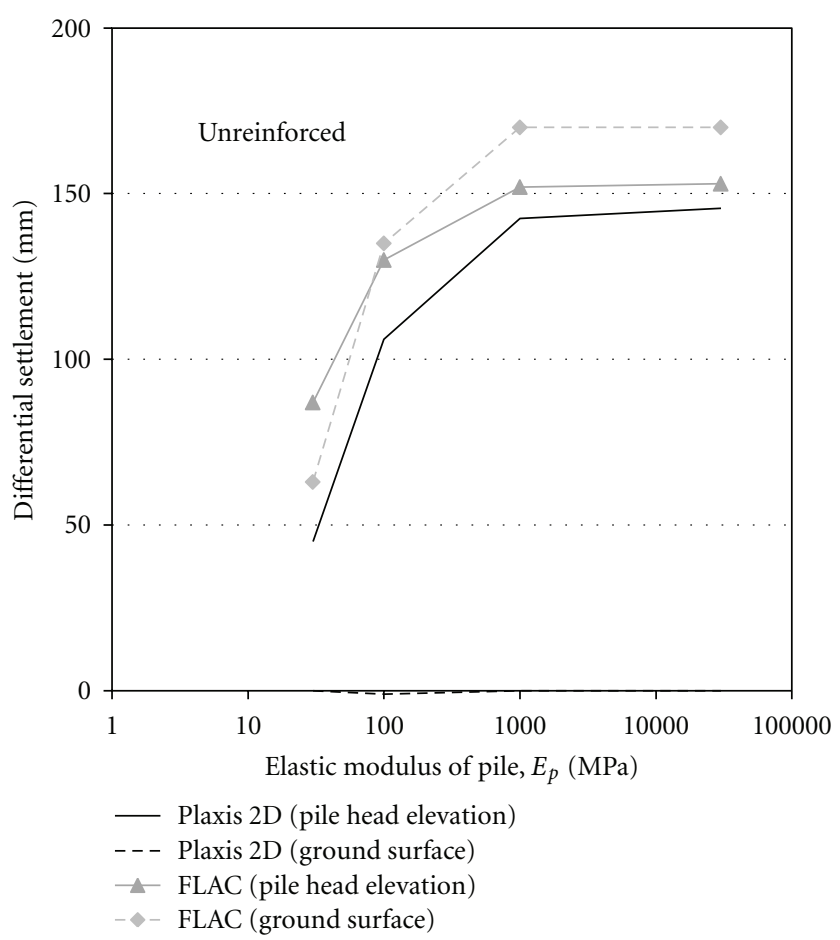

Figure 15: Influence of embankment height on differential settlements (unreinforced case).

The vertical stresses below the geosynthetic reinforcement had a magnitude just greater than that of the vertical stresses above the geosynthetic at the centreline of the pile $(0.0 \mathrm{~m}$ from the centreline of the pile, Figure 16). This difference was due primarily to the transfer of the tension above the geosynthetic reinforcement and to a lesser degree the small load from the embankment fill on top of the pile cap but under the geosynthetic reinforcement.

Plaxis 2D recorded a peak vertical stress at the outer edge of the pile cap 19.2\% greater in magnitude than FLAC, Figure 16 (below geosynthetic). However, the vertical stress at the center of the pile below the geosynthetic recorded by FLAC was $23 \%$ greater than the comparative values from Plaxis $2 \mathrm{D}$. At the pile cap edge, the vertical stress concentration below the reinforcement peaked by a factor of approximately 2.22 in Plaxis 2D and 1.64 in FLAC in comparison to the loading at the centreline of the pile (Figure 16). The total vertical load recorded by FLAC acting directly above the pile head below the geosynthetic was approximately $26 \%$ greater than Plaxis 2D.

The total vertical stress acting above the geosynthetic reinforcement recorded by FLAC yielded a peak vertical stress approximately 25\% greater than Plaxis 2D (Figure 16). The total vertical load acting above the geosynthetic reinforcement computed by FLAC was 5.5\% greater than comparative Plaxis 2D value. The total vertical load acting directly above the pile head was $17 \%$ greater in FLAC compared to Plaxis 2D.

The unreinforced case (Figure 17), produced similar results to the reinforced case (Figure 16). The magnitude of vertical load computed by FLAC was greater than Plaxis 2D 


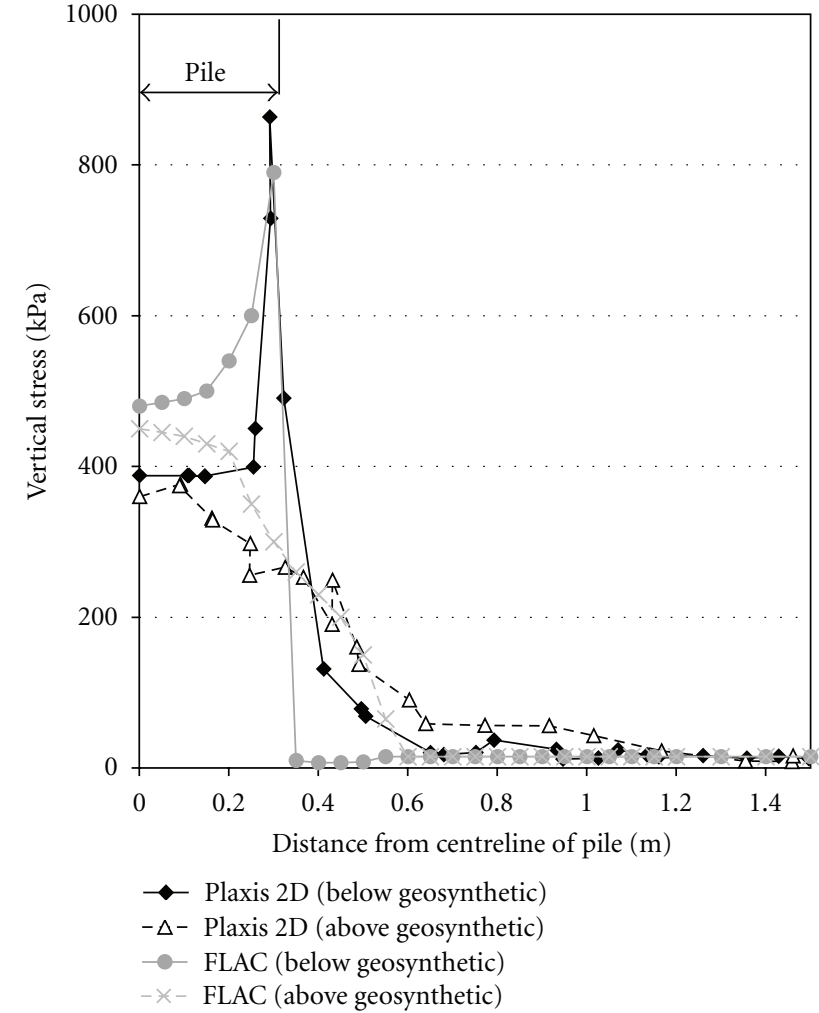

FIGURE 16: Vertical stress distribution at distances from center of pile (reinforced case).

( $24 \%$ greater for peak vertical stress, $15 \%$ greater for directly above the pile caps only but $7.3 \%$ less for the total vertical load across the $1.5 \mathrm{~m}$ span).

In summation, the FLAC analysis computed greater magnitudes of vertical stress in all cases (reinforced and unreinforced both above and below the reinforcement) in comparison to Plaxis 2D. However, an interesting trend in the differential in absolute stresses was observed. With increase of the focalized area of analysis from a concentrated area (above pile caps) to a bigger area (whole pile span), the differential between FLAC and Plaxis 2D decreased, declining from $25 \%$ to $5 \%$, peak stress at pile cap edge to total load over the pile span.

4.4. Soil Arching. Figure 18 illustrates that the soil arching ratio decreased with an increase in the embankment height. Plax is 2D replicated the FLAC reinforced and unreinforced cases analyses with a high degree of consistency for both characteristic trend and absolute values (Figure 18).

For an increase in embankment height for both cases (reinforced and unreinforced), the arching ratio decreased, suggesting that full arching was nearly developed. At low embankment heights, the shear resistance within the embankment fill was insufficient to develop full arching. As the embankment height increased, a greater magnitude of vertical load required support; vertical displacement between pile caps increased and the shear stresses within the embankment also increased. The increase in shear stress increased the degree of load transfer within the embankment

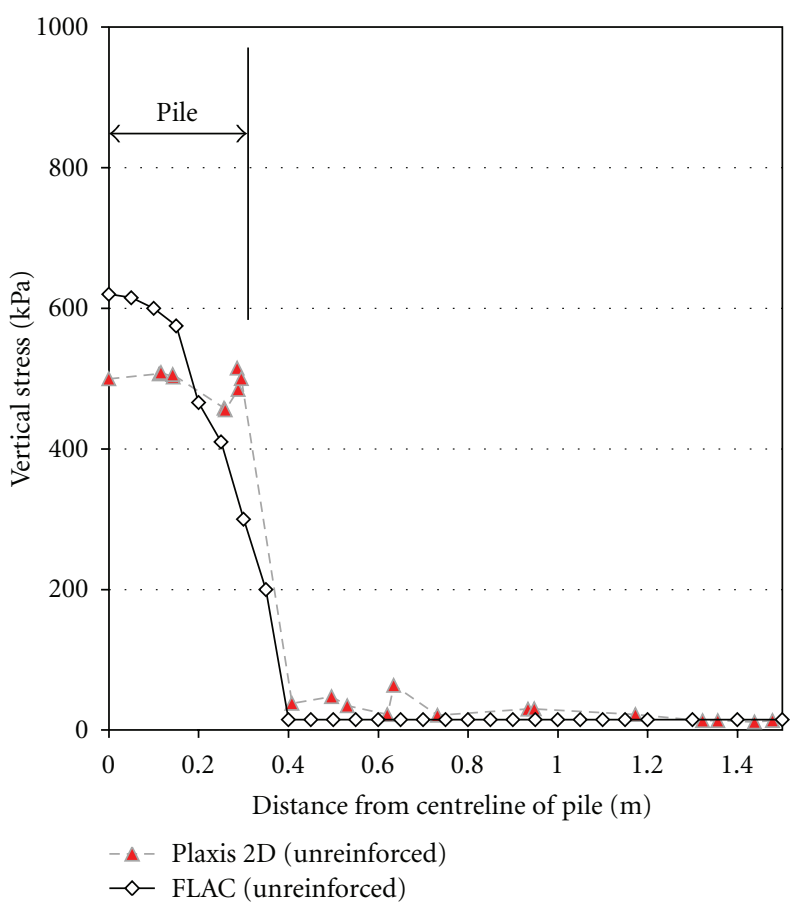

Figure 17: Vertical stress distribution at distances from center of pile (unreinforced case).

and resulting in a reduction in the soil arching ratio (Figure 18).

Both Plaxis 2D and FLAC showed that the soil arching ratio decreased in a reasonably linear fashion for both reinforced and unreinforced cases until the embankment height exceeded the height suggested for full arching (critical height), which Naughton [42] reported was between 1.25 and 2.4 times the clear spacing between adjacent pile caps edges $(s-a)$, where $s$ is the pile span and $a$ is the pile head size. The degree of arching increased rapidly (soil arching ratio decrease) for an initial increase from low embankment heights $(1.0 \mathrm{~m}$ to $2.0 \mathrm{~m})$. Plaxis $2 \mathrm{D}$ and FLAC recorded a lower rate of soil arching, suggesting greater load transfer onto the pile caps, for embankment heights greater than $3.0 \mathrm{~m}$ (Figure 18). The location of the inflection point $(H=$ $3.0 \mathrm{~m}$ ) of the computed relationship on the increase of soil arching ratio with increasing embankment height was within the range of heights suggested by Naughton [42] in both Plaxis 2D and FLAC.

Inclusion of geosynthetic reinforcement to the piled embankment structure reduced the settlements of the embankment fill in between the adjacent pile cap edges. As the stiffness of the geosynthetic reinforcement increased, both the maximum and the differential settlements at the base of the embankment, midspan between adjacent piles, reduced (Figures 8 and 13). Shear stresses developed within the embankment fill were a function of the settlements at the pile head elevation. The greater the settlements, the greater the shear stresses, load transfer by the embankment fill material, and degree of soil arching. An increase in the geosynthetic reinforcement stiffness reduced settlements in 


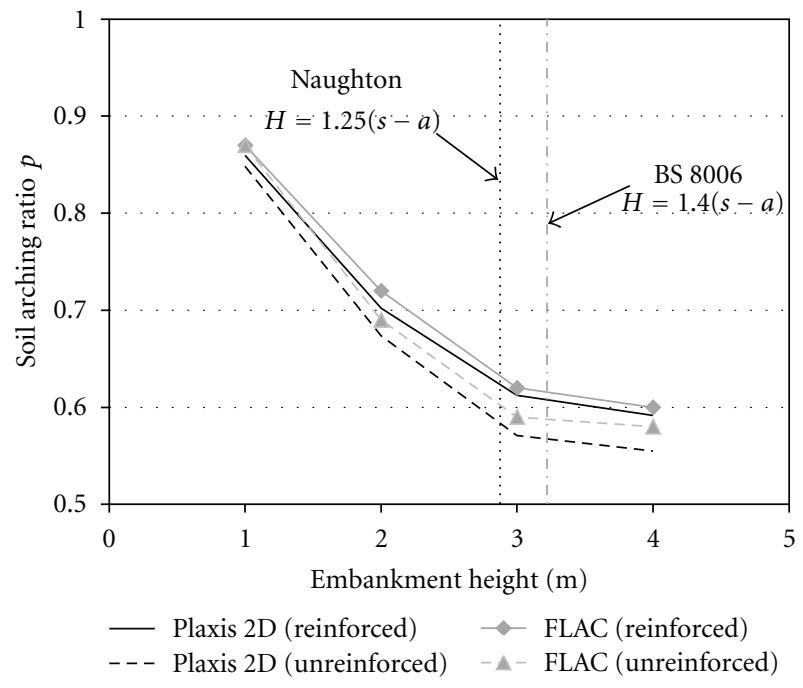

FIGURE 18: Relationship of embankment height and soil arching ratio.

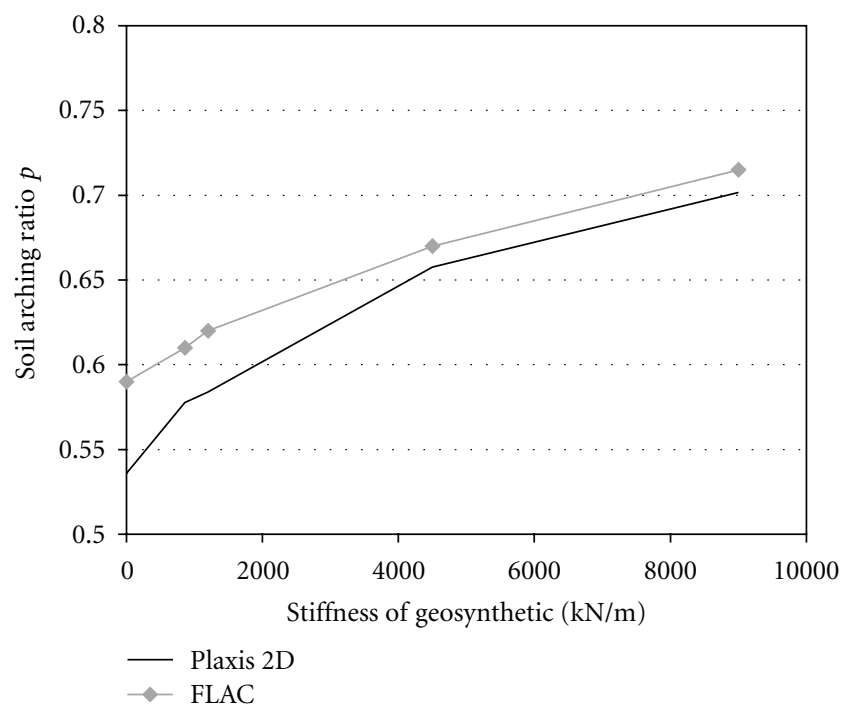

Figure 19: Relationship of geosynthetic reinforcement stiffness and soil arching ratio.

unison with a reduction in degree of arching (increase in soil arching ratio) within the embankment fill.

Plaxis 2D and FLAC both gave similar magnitudes and trends for the soil arching ratio (Figure 19). The initial inclusion of the geosynthetic reinforcement (stiffness of $860 \mathrm{kN} / \mathrm{m}$ ) yielded the greatest increase in soil arching ration in Plaxis 2D (7.5\% increase) in comparison to FLAC (3.3\% increase) (Figure 19). The rate of increased soil arching ratio for an increase in geosynthetic reinforcement stiffness reduced for both Plaxis 2D and FLAC (Figure 19). For an increase in the geosynthetic reinforcement stiffness, the difference between Plaxis 2D and FLAC converged.

The pile elastic modulus significantly influenced the soil arching conditions within the structure and yielded similar responses in both Plaxis 2D and FLAC. As the pile elastic

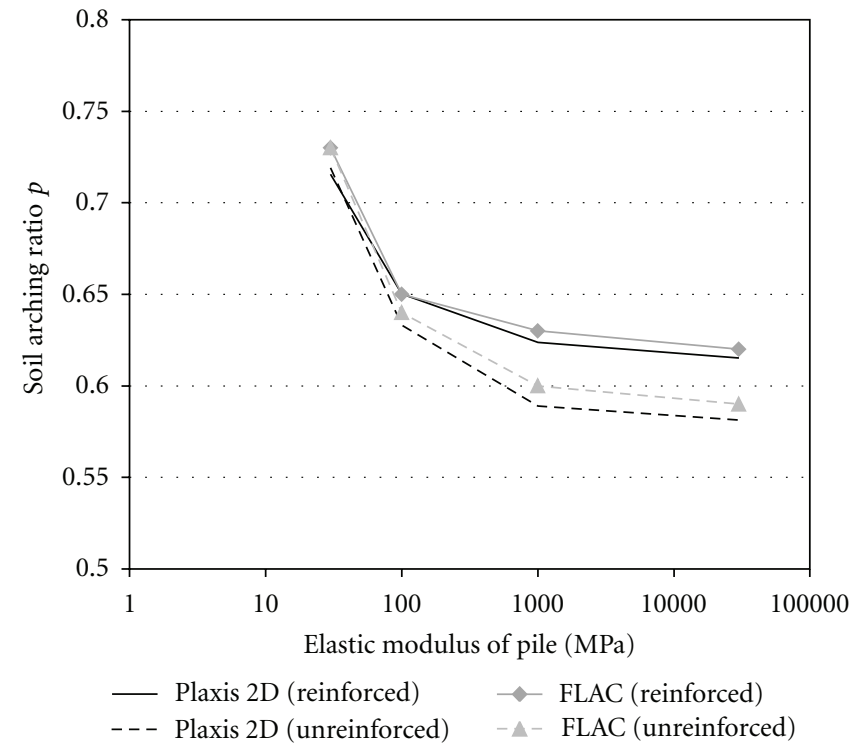

FIGURE 20: Relationship of pile elastic modulus and the soil arching ratio.

modulus increased, the difference in stiffness between the pile and that of the underlying soft soil diverged, resulting in higher differential settlements at the midspan between adjacent piles (Figures 14 and 15). Higher differential settlements mobilise larger shear stresses resulting in an increased degree of arching within the embankment fill (Figure 20). The reinforced case recorded greater soil arching ratios (lower degree of soil arching) than the unreinforced case for both Plaxis 2D and FLAC (Figure 20). The geosynthetic inhibited the development of the differential settlements required for the development of soil arching within the embankment fill.

As illustrated in Figure 20, the soil arching ratio decreased for an increase in the pile elastic modulus, with both Plaxis 2D and FLAC showing relatively good agreement. The overall characteristic response in the models was identical for both Plaxis 2D and FLAC, with the characteristic relationship of the soil arching ratio with pile elastic modulus (Figure 20) being the inverse of the differential settlements response (Figures 14 and 15). The most significant reduction in the soil arching ratio occurred for the initial increase in the pile elastic modulus from $30 \mathrm{MPa}$ to $100 \mathrm{MPa}$, and further increase in the elastic pile modulus from $1,000 \mathrm{MPa}$ to $30,000 \mathrm{MPa}$ yielded no improvement in the soil arching ratio (approximately 1.5\%) (Figure 20). Plaxis 2D consistently gave soil arching ratios marginally lower than the comparative FLAC values for both the reinforced and unreinforced cases (Figure 20).

Plaxis 2D and FLAC gave, with an acceptable degree of accuracy, similar soil arching responses, with the Plaxis 2D values marginally lower in magnitude than FLAC. The results suggest that a marginally higher degree of soil arching occurs in Plaxis 2D than in FLAC.

4.5. Stress Concentration. The stress concentration ratio $(n)$ was defined as the ratio of the stress on the pile caps to the 
stress acting on the soft soil layer underlying the reinforcement. A greater magnitude of stress concentration ratio $(n)$ corresponds to an increase in the degree of soil arching.

Figure 21 illustrates that the stress concentration ratio increased for an increase in embankment height. Plaxis 2D replicated the characteristic response of the stress concentrations with embankment height given by FLAC (Figure 21). However, Plaxis 2D recorded absolute values of stress concentrations consistently higher than FLAC. The stress concentration ration given by Plaxis $2 \mathrm{D}$ and FLAC diverged as the embankment height increased (Figure 21), with the divergence more pronounced for the reinforcement than the unreinforced case.

The numerical analysis suggested that the greatest rate of increase in the stress concentration ratio was for the initial increase in embankment height from $1.0 \mathrm{~m}$ to $2.0 \mathrm{~m}$ (Figure 21). For an initial increase in the embankment height the stress concentration ratio from Plaxis 2D increased at the same rate, although lower in magnitude (Figure 21) than in FLAC. For an embankment height greater than $2.0 \mathrm{~m}$, the response from Plaxis 2D and FLAC diverged. The stress acting on the pile head was over a relatively small area $(0.35 \mathrm{~m}$ in width). It was noted that even with the inclusion of the maximum allowable number of nodes within Plaxis $2 \mathrm{D}$, the output of data such as stress concentrations acting on relatively small lengths was prone to volatility in the extraction using the cross section tool from the deformed mesh in the absolute values due to the insufficient number of nodes in these areas of high stress concentrations. The volatility in the output of the stress concentration data is a possible explanation for divergence of the Plaxis 2D and FLAC responses (Figure 21). The rate of increase of stress concentration ratio reduced when the height of the embankment was within the range suggested by Naughton [42] but was marginally lower than the height suggested by BS 8006 [18] for full arching (Figure 21).

For both Plaxis 2D and FLAC, increasing the stiffness of the geosynthetic reinforcement yielded an increase in the stress concentration at the pile head. As expected an increase in the degree of soil arching (reduction of soil arching ratio) corresponded to an increase in stress concentration. Increasing the stiffness of the geosynthetic reinforcement inhibited the development of shear stresses, thus, a reduction in the degree of soil arching in the embankment fill occurred (Figure 19). The influence of load transfer due to soil arching on the increase of the stress concentration ratio (Figure 22) reduced as the geosynthetic reinforcement stiffness increased, which was attributed to the increased load transfer from the reinforcement platform outweighing the reduction in load transfer due to arching within the embankment fill. Plaxis $2 \mathrm{D}$ and FLAC both consistently simulated this phenomenon (Figure 22). The greatest incremental increase in load transfer (stress concentration ratio increase, Plaxis 2D $52 \%$ and FLAC $41 \%$ ) corresponded to the initial inclusion of the reinforcement at the base of the embankment. Both Plaxis 2D and FLAC computed lower rates of stress concentration increase for further increases in reinforcement stiffness (Figure 22).

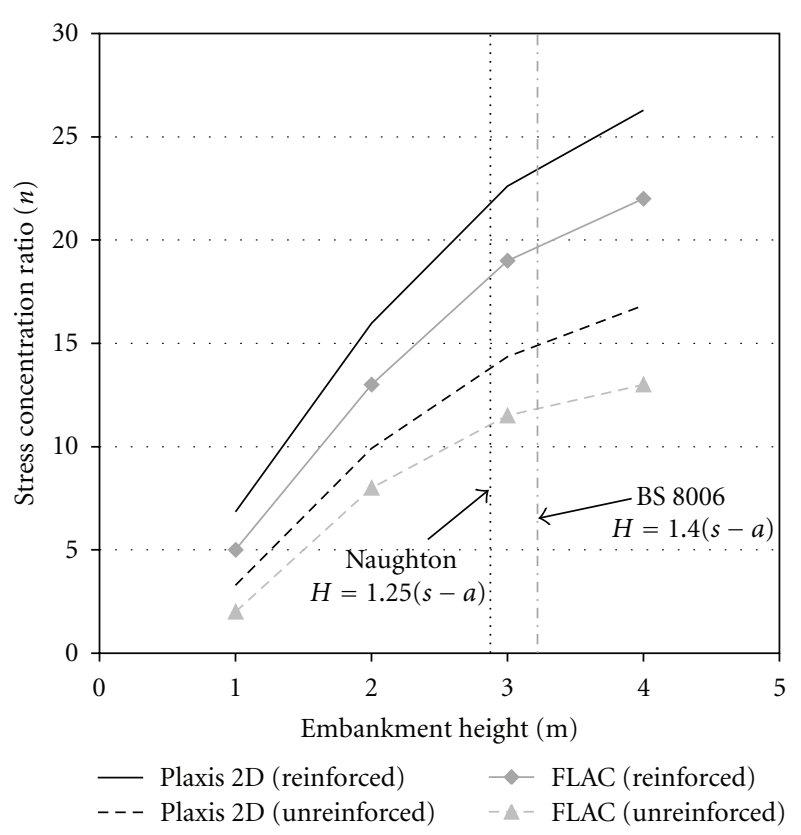

FIGURE 21: Relationship of embankment height and stress concentration ratio.

Figure 23 illustrates that the increase in the pile elastic modulus yielded an increase in stress concentration ratio. Plaxis 2D and FLAC produced the same characteristic response in the stress concentration with embankment height (Figure 21). The reinforced case produced a difference of $5 \%$ and unreinforced case $20 \%$ between Plaxis $2 \mathrm{D}$ and FLAC, respectively.

Both Plaxis 2D and FLAC suggested that the initial increase in the pile elastic stiffness from $30 \mathrm{MPa}$ to $100 \mathrm{MPa}$ yielded the greatest increase in stress concentration at the pile head (reinforced case: 43\% Plaxis 2D and 47\% FLAC, unreinforced case: 25\% Plaxis 2D and 26\% FLAC) (Figure 23). FLAC suggested that the stress concentration ratio was independent of the elastic pile modulus. Reinforced and unreinforced Plaxis 2D showed that the stress concentration ratio increased for both the reinforced (12\%) and unreinforced $(9.0 \%)$ cases. The analysis suggested that Plaxis 2D simulation of the soil arching occurring within the embankment fill was more sensitive to a parametric variation than FLAC.

Plaxis 2D produced a similar response in stress concentration within the embankment fill as FLAC. However, Plaxis $2 \mathrm{D}$ recorded absolute values of stress concentration greater in magnitude than FLAC, which was entirely consistent with lower magnitudes of soil arching ratio (Figures 18, 19, and 20).

4.6. Tension in Geosynthetic Reinforcement. The primary aim of including geosynthetic reinforcement in a piled embankment structure is to reduce the settlements in between the pile spacing by maximizing the stress concentration on the pile caps. Increasing the stress concentration on the pile caps effectively leads to a reduction in stress concentration acting on the soft soil, thus a reduction in settlements over the 


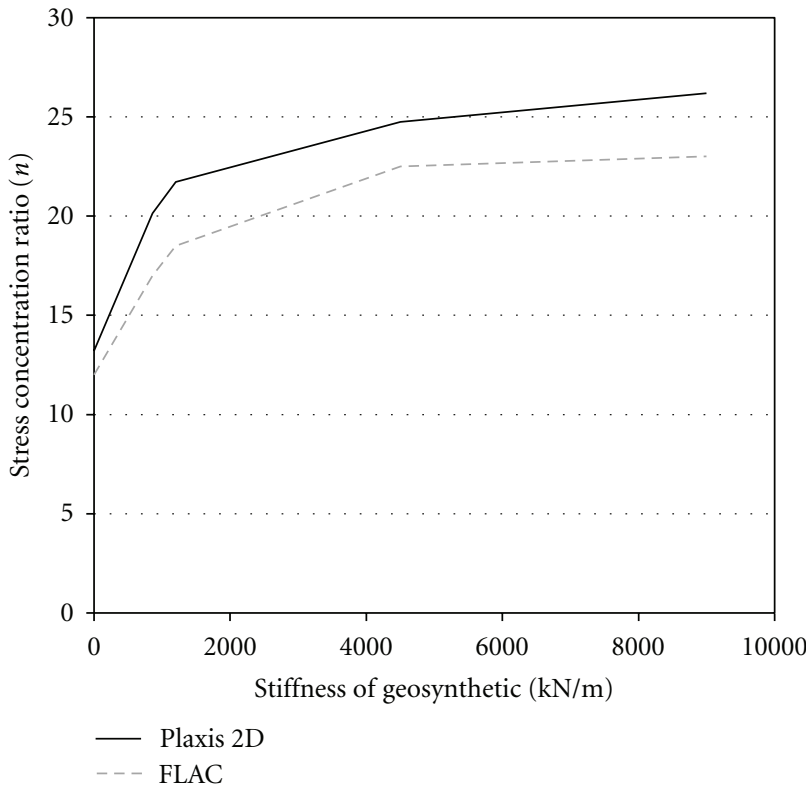

FIGURE 22: Relationship of embankment height and stress concentration ratio.

pile clear spacing is possible. The geosynthetic is somewhat restrained in the horizontal plane by the vertical stresses above the reinforcement at the pile caps effectively pining the reinforcement to the top of the pile caps. The load carried by the geosynthetic reinforcement over the clear span between adjacent piles attempts to pull out the reinforcement from the top of the pile caps.

In this study the geosynthetic reinforcement underwent relatively low magnitudes of horizontal deformation above the pile caps. As the reinforcement approached the pile cap edge, reinforcement deformation increased significantly. The result was a significant increase in the tension in the reinforcement at this particular location (pile cap edge) (Figure 24).

The tension in the reinforcement in both Plaxis 2D and FLAC, at the centreline of the pile clear span, was $98 \%$ less than the maximum tension in the reinforcement at the edge of the pile cap (Figure 24). The tension in the reinforcement decreased virtually to zero at the centreline of the pile span ( $1.5 \mathrm{~m}$ from the centreline of the pile centreline) for both Plaxis 2D and FLAC. FLAC computed a maximum tension in the reinforcement approximately $31.1 \%$ greater in magnitude than Plaxis 2D for the generic case model (Figure $24)$. Tensions recorded at the centre of the pile cap $(0.0 \mathrm{~m}$ on $x$-axis, Figure 24) were approximately $78 \%$ and $70 \%$ lower than the peak tensions recorded at the pile cap edge for both Plaxis 2D and FLAC, respectively. Whilst FLAC computed a greater magnitude of maximum tension in the reinforcement than Plaxis 2D, Plaxis 2D recorded a $17 \%$ higher average reinforcement strain than FLAC. The densification of the discretized nodes above the pile head was lower (for the most dense 15-node mesh) than FLAC resulting in a localized peak not been as accurately captured by Plaxis $2 \mathrm{D}$.

Figure 25 illustrates that the maximum tension in the reinforcement increased for an increase in the embankment

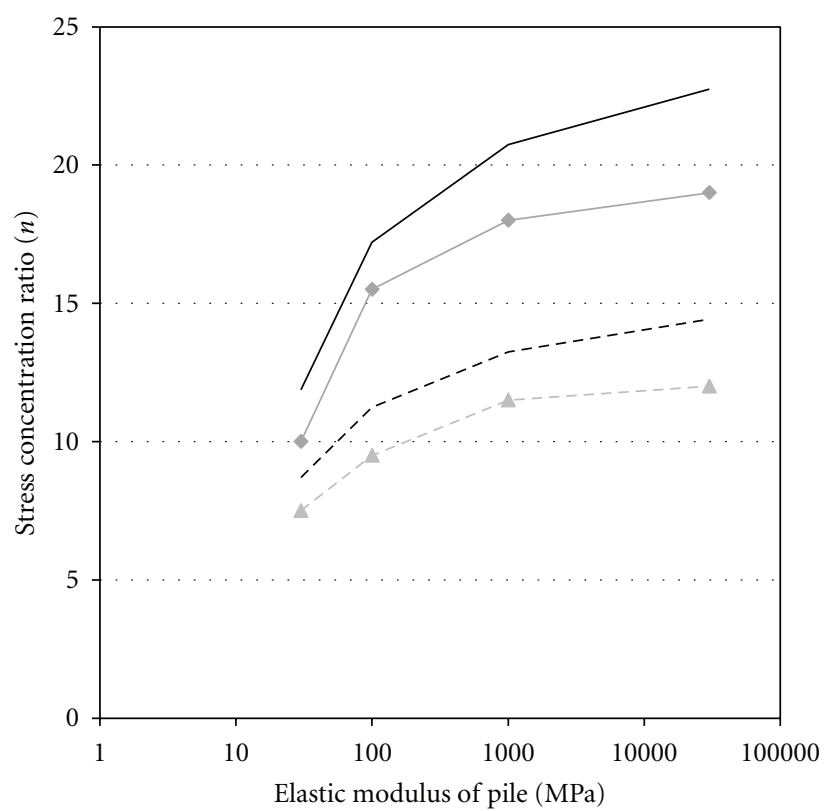

$\begin{array}{lll}- \text { Plaxis 2D (reinforced) } & - \text { FLAC (reinforced) } \\ --- \text { Plaxis 2D (unreinforced) } & -{ }_{-} \text {FLAC (unreinforced) }\end{array}$

FIGURE 23: Relationship of embankment height and stress concentration ratio.

height. Tension computed by both Plaxis $2 \mathrm{D}$ and FLAC increased in an almost linear fashion, with Plaxis 2D computing lower maximum tensions in the reinforcement (Figure 25). An increase in the embankment height from $1.0 \mathrm{~m}$ to $4.0 \mathrm{~m}$ yielded an increase in the maximum tension of $109 \%$ and $143 \%$ for Plaxis2D and FLAC, respectively. All tensions had a maximum value at the edge of the pile cap.

The maximum tensions computed by both Plaxis 2D and FLAC diverged for an increase in embankment height (Figure 25). The analysis suggested the lower maximum tensions and lower differential in tension produced by Plaxis 2D were due to a greater degree of load transfer to the pile head through soil arching and therefore less load requiring support by the geosynthetic reinforcement. Consequently, Plaxis 2D recorded a lower rate of increase in the maximum tensions compared to FLAC for an increase in embankment height (Figure 25).

Between adjacent piles the resulting settlement of the reinforcement continued to increase in magnitude until an equilibrium state (strain compatibility) was achieved. In relation to the settlement of the reinforcement, equilibrium can be defined as when the support offered by the soft soil underlying the reinforcement combined with the load carrying capacity of the reinforcement achieved a combined structural stiffness that was equal to the loading from the embankment fill above the reinforcement. In this particular calculation the elastic stiffness of the underlying soft subsoil remained constant as did the embankment fill characteristics. As the stiffness of the geosynthetic reinforcement increased, the maximum tension recorded in the 


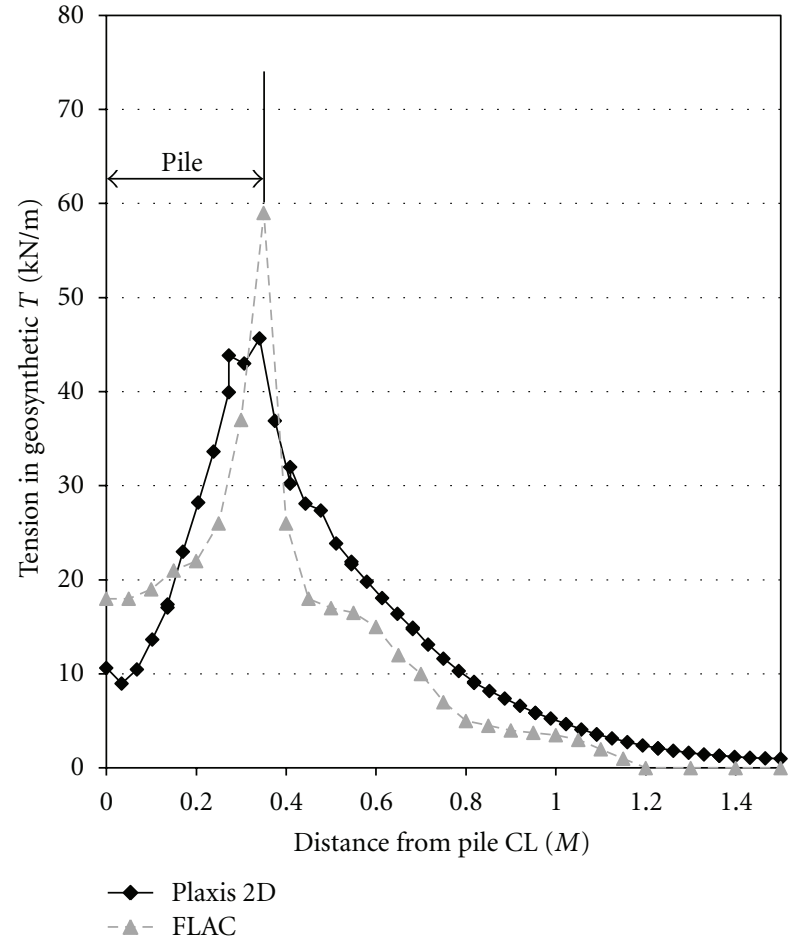

Figure 24: Distribution of tension in the geosynthetic reinforcement.

reinforcement also increased. The stiffer the geosynthetic reinforcement, the greater the resistance to deformation due to the weight of the embankment fill carried by the geosynthetic and the lower the support required from the soft soil to achieve strain compatibility. Figure 26 illustrates the relationship of geosynthetic reinforcement stiffness and maximum tension recorded in the geosynthetic reinforcement with the embankment height held constant. The load on the reinforcement from the embankment fill remained constant (no change in geometry). The increase in reinforcement stiffness attracted more load, thus reducing the load on the soft soil and increasing the maximum tensions in the reinforcement.

Figure 26 suggests Plaxis 2D replicated FLAC both in characteristic response and absolute values for the lower range stiffness $(0 \mathrm{kN} / \mathrm{m}$ to approximately $3,000 \mathrm{kN} / \mathrm{m})$ but diverged for further increase in reinforcement stiffness with Plaxis 2D underpredicting reinforcement tension relative to FLAC. The relationship of maximum tension in the reinforcement with geosynthetic stiffness was the inverse of the maximum settlement response (Figure 8).

Increasing the pile elastic modulus increased the maximum tension in the reinforcement. The increase in the pile modulus increased the difference between the elastic stiffness of the pile and the elastic stiffness of the underlying soft soil, resulting in an increase in differential settlements and a corresponding increase in the maximum reinforcement tensions (Figure 27). The characteristic shape of the relationship of both maximum tensions/differential settlements and pile modulus was similar for both Plaxis 2D and FLAC (Figure 27 (max tensions) and Figures 14 and 15

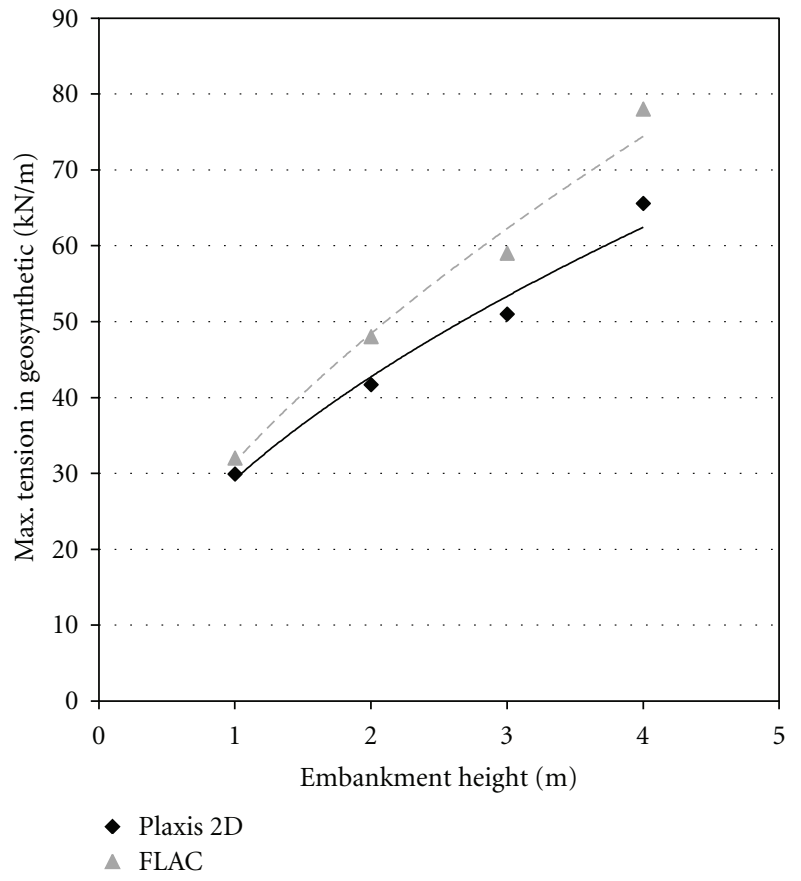

FIGURE 25: Distribution of tension in the geosynthetic reinforcement.

(differential settlement)). Plaxis 2D replicated the response of the maximum tensions in the geosynthetic reinforcement for a range of pile elastic modulus but with consistently lower magnitudes of maximum tensions. Both FLAC and Plaxis 2D suggested that for an increase in the pile elastic modulus from $1,000 \mathrm{MPa}$ to $30,000 \mathrm{MPa}$, an insignificant increase in maximum tension occurred. Absolute maximum tensions from FLAC were consistently $13.2 \mathrm{kN} / \mathrm{m}$ greater than Plaxis $2 \mathrm{D}$ however, percentage-wise, the differential was $83 \%$ to $26 \%$ for an increase in pile elastic modulus from $30 \mathrm{MPa}$ to 30,000 MPa.

Overall, Plaxis 2D replicated the FLAC analysis during the parametric variation. The magnitudes of the absolute tensions recorded by Plaxis 2D were consistently lower than the comparative FLAC values.

\section{Conclusions}

The objective of this study was to benchmark an FEM against an FDM analysis of a piled embankment. Plaxis 2D v9.0 (an FEM code) was used to replicate the analysis of GRPEs using FLAC (an FDM code) originally reported by Han and Gabr [1]. The primary difference between the analyses was the selection of numerical models for both the embankment fill and foundation soil. The original analysis by Han and Gabr [1] utilised a nonlinear hyperbolic elastic model developed by Duncan and Chang [38] for both embankment fill and foundation soil. However in the Plaxis 2D analysis a hardening soil model, which involves stressdependent stiffness similar to Duncan and Chang [38], Plaxis [26], was used for the foundation soil. A Mohr Coulomb model was used for the embankment fill. 


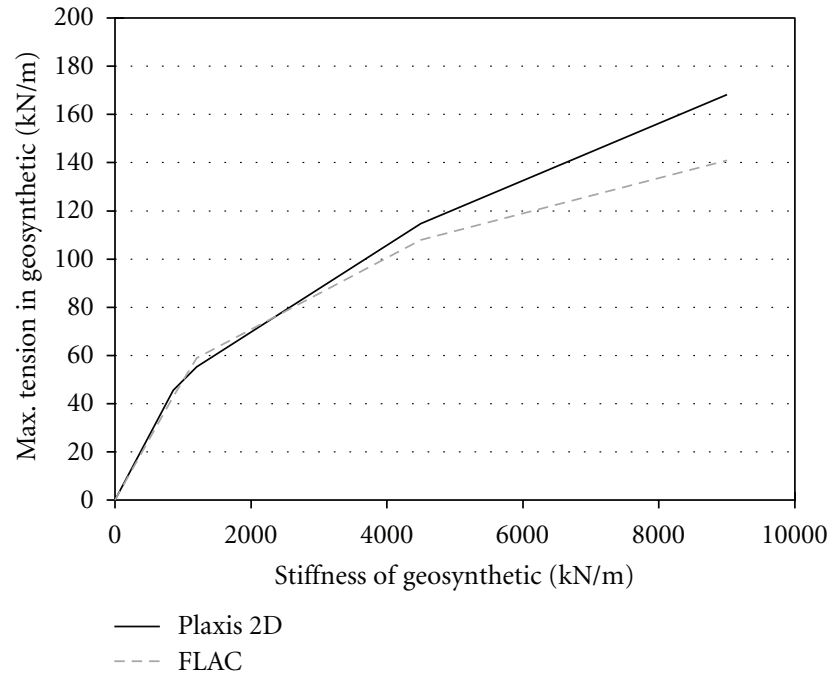

FIGURE 26: Distribution of tension in the geosynthetic reinforcement.

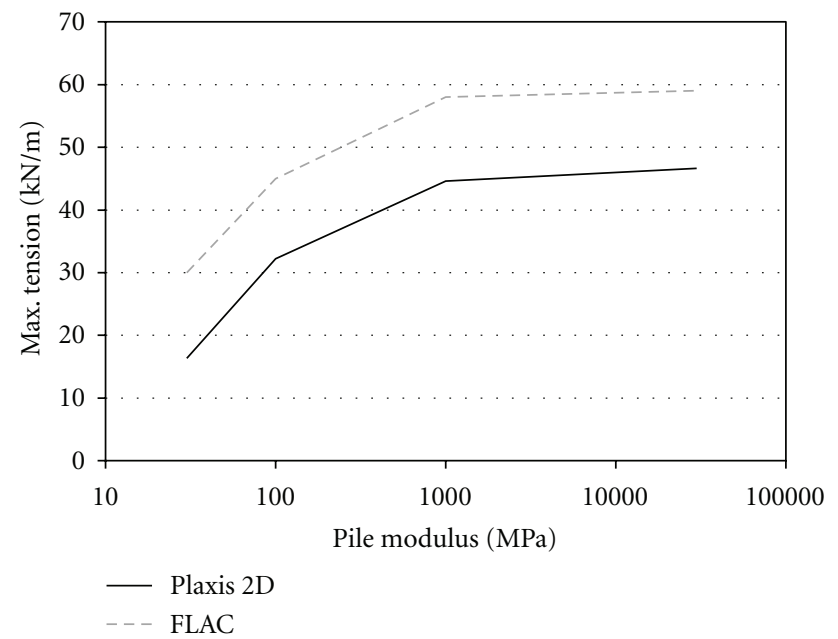

FIGURE 27: Distribution of tension in the geosynthetic reinforcement.

A parametric study in Plaxis 2D found that 6- and 15node elements predicted similar tensions in the geosynthetic reinforcement. However, settlements predicted by the 15node elements were approximately $20 \%$ higher than the 6 node element density.

Overall Plaxis 2D v9.0 replicated reasonably well both the characteristic trends and absolute values given by FLAC in all parameters investigated. Plaxis $2 \mathrm{D}$ consistently replicated the FLAC outputs for deformational, loading, and load transfer mechanism (soil arching) response within the reinforced piled embankment structure with a reasonable degree of accuracy.

Plaxis 2D computed lower maximum and differential settlements than FLAC. Plaxis 2D suggested that for pile elastic modulus greater than $30 \mathrm{MPa}$, an insignificant reduction in maximum settlements would occur, while FLAC showed a consistent reduction in the maximum settlements under the same conditions.
FLAC computed greater magnitudes of vertical stress in all cases (reinforced and unreinforced both above and below the reinforcement) in comparison to Plaxis 2D. Plaxis $2 \mathrm{D}$ suggested lower magnitudes of vertical stresses than FLAC when the subject area of examination was quite small and concentrated, for example, on the pile cap. Plaxis $2 \mathrm{D}$ recorded stress concentrations at the pile head greater in magnitude than FLAC, which was entirely consistent with lower computed magnitudes of soil arching ratios. A possible error in the vertical stress distribution in Plaxis 2D may have occurred due to extrapolation of values by the cross section tool, which intercepts elements within the deformed discretized mesh. This may have affected the vertical stress distribution, but also the soil arching and stress concentration ratios which are both computed from the vertical stress predicted by Plaxis 2D.

Tensions developed within the geosynthetic reinforcement determined from Plaxis 2D were in reasonably good agreement with FLAC both in characteristic response for a parametric variation and also absolute values. However, maximum tensions computed by Plaxis $2 \mathrm{D}$ were consistently lower in magnitude than FLAC. The ratio of the maximum tension recorded at the pile cap edge to the tension recorded at the pile center was greater for Plaxis 2D than FLAC, with the average strain along the reinforcement being greater in Plaxis 2D than FLAC.

The analysis suggests that the FEM and FDM numerical approaches were in overall good agreement for the numerical modeling of a geosynthetic reinforced piled embankment. Similitude conditions exist in both the numerical techniques to consistently simulate the response of structural and soil elements in their behaviour. FDM benefited from the advantage of the ability to discretize the element grid mesh to a higher degree of densification than Plaxis 2D but with the burden of increased computing time. Consequently, forces/deformations localized to a small concentrated area can be simulated and extrapolated for analyses with a greater degree of accuracy than the FEM approach.

Plaxis 2D and FLAC developed characteristic trends under a variation of reinforcement stiffness that can be considered agreeable in nature (trends) but for some parameters slightly divergent in their absolute values.

\section{Notation}

$c$ : Cohesion of the foundation soil or fill

$p_{b}$ : Applied pressure on the top of the trapdoor or geosynthetic

$\rho$ : Soil arching ratio

$\gamma$ : Unit weight of embankment fill

$H$ : Height of embankment

$q_{o}$ : Uniform surcharge on embankment surface

$n$ : Stress concentration ratio

$\sigma_{c}$ : Stress on the pile caps

$\sigma_{s}$ : Stress imparted on the soft soil layer

$J:$ Stiffness of the geosynthetic reinforcement

$M$ : Young's modulus component

$T$ : Tension $n$ the geosynthetic reinforcement 
$W_{1}$ : Weight of the fill above the soft soil and between the pile caps

$W_{2}$ : Weight of the fill above the pile caps

$M$ : Poisson's ratio

$\gamma: \quad$ Unit weight of fill

$\tau$ : Shear resistance along soil wedge

$\varphi$ : Friction angle of foundation soil or fill

$\psi:$ Dilatancy angle of foundation soil or fill

$E_{50}$ : Triaxial unloading stiffness

$E_{\text {ur: }}$ : The oedometer loading stiffness

$R_{f}:$ Failure ratio

$E_{p}$ : Elastic modulus of the pile material

$E_{g}$ : Elastic modulus of the geosynthetic

$s: \quad$ The pile spacing

$a$ : The size at the pile head

$t$ : The thickness of the geosynthetic reinforcement.

\section{References}

[1] J. Han and M. A. Gabr, "Numerical analysis of geosyntheticreinforced and pile-supported earth platforms over soft soil," Journal of Geotechnical and Geoenvironmental Engineering, vol. 128, no. 1, pp. 44-53, 2002.

[2] K. Jennings and P. J. Naughton, "Lateral deformation under the side slopes of piled embankments," in Proceedings of the 9th International Conference on Geosynthetics, vol. 4, pp. 19251928, Guarujá, Brazil, 2010.

[3] K. Jennings and P. J. Naughton, "Lateral deformation under the side slopes of piled embankments," in Proceedings of the Geo-Frontiers, pp. 142-151, Dallas, Tex, USA, March 2011.

[4] G. Kempton, D. Russell, N. D. Pierpoint, and C. J. F. P. Jones, "Two and three dimensional numerical analysis of the performance of piled embankments," in Proceedings of the 6th International Conference on Geosynthetics, 1998.

[5] W. M. Reid and N. W. Buchanan, "Bridge approach support piling," in Piling and Ground Treatment, pp. 267-274, Thomas Telford, London, UK, 1984.

[6] J. Han, "Design and construction of embankments on geosynthetic reinforcement platforms supported by piles," in Proceedings of the ASCE/PaDOT Geotechnical Seminar, pp. 66-84, Central Pennsylvania Section, ASCE and Pennsylvania Department of Transportation, 1999.

[7] H. Rathmayer, "Piled embankment supported by single pile caps," in Istanbul Conference on Soil Mechanics and Foundation, Istanbul, Turkey, 1975.

[8] K. Q. Lin and I. H. Wong, "Use of deep cement mixing to reduce settlements at bridge approaches," Journal of Geotechnical and Geoenvironmental Engineering, vol. 125, no. 4, pp. 309-320, 1999.

[9] D. Russell and N. Pierpoint, "An assessment of design methods for piled embankments," Ground Engineering, vol. 30, no. 10, pp. 39-44, 1997.

[10] R. J. Varuso, J. B. Grieshaber, and M. S. Nataraj, "Geosynthetic reinforced levee test section on soft normally consolidated clays," Geotextiles and Geomembranes, vol. 23, no. 4, pp. 362383, 2005.

[11] R. K. Rowe and A. L. Li, "Geosynthetic-reinforced embankments over soft foundations," Geosynthetics International, vol. 12, no. 1, pp. 50-85, 2005.
[12] D. T. Bergado and C. Teerawattanasuk, "2D and 3D numerical simulations of reinforced embankments on soft ground," Geotextiles and Geomembranes, vol. 26, no. 1, pp. 39-55, 2008.

[13] L. Briançon and P. Villard, "Design of geosynthetic-reinforced platforms spanning localized sinkholes," Geotextiles and Geomembranes, vol. 26, no. 5, pp. 416-428, 2008.

[14] A. L. Li and R. K. Rowe, "Effects of viscous behavior of geosynthetic reinforcement and foundation soils on the performance of reinforced embankments," Geotextiles and Geomembranes, vol. 26, no. 4, pp. 317-334, 2008.

[15] R. K. Rowe and C. Taechakumthorn, "Combined effect of pvds and reinforcement on embankments over rate-sensitive soils," Geotextiles and Geomembranes, vol. 26, no. 3, pp. 239-249, 2008.

[16] S. W. Abusharar, J. J. Zheng, B. G. Chen, and J.-H. Yin, "A simplified method for analysis of a piled embankment reinforced with geosynthetics," Geotextiles and Geomembranes, vol. 27, no. 1, pp. 39-52, 2009.

[17] J. Love and G. Milligan, "Design methods for basally reinforced pile-supported embankments over soft ground," Ground Engineering, vol. 36, no. 3, pp. 39-43, 2003.

[18] British Standard BS 8006, Code of Practice for Strengthened/Reinforced Soils and Other Fills, British Standard Institution, London, UK, 2010.

[19] EBGEO, Empfehlung fur den Entwurf und die Berechnung von Erdkorpern mit Bewehrung aus Geokunstoffen, (unveroffentlicht), Ausgabe 2007.

[20] B. Carlsson, Reinforced Soil, Principles for Calculation, Terratema A. B., Linkoping, Sweden, 1987.

[21] W. J. Hewlett and M. F. Randolph, "Analysis of piled embankments," Ground Engineering, vol. 21, no. 3, pp. 12-18, 1988.

[22] D. Russell, P. J. Naughton, and G. Kempton, "A new design procedure for piled embankments," in Proceedings of the56th Canadian Geotechnical Conference and the NAGS Conference, pp. 858-865, 2003.

[23] G. Svanø, T. Ilstad, G. Eiksund, and A. Want, "Alternative calculation principle for design of piled embankments with base reinforcement," in Proceedings of the 4th Ground Improvement Geosystems in Helsinki, 2000.

[24] Dutch CUR design guideline for piled embankments, CUR 2262010.

[25] N. R. Krishna, Numerical modeling and analysis of pile supported embankments, M.S. thesis, University of Texas at Arlington, 2006.

[26] PLAXIS BV, PLAXIS 2D Version 8, 2004, Edited by R. B. J. Brinkgreve, W. Broere, and D. Waterman.

[27] FLAC, Fast Langrangian Analysis of Continua, Version 3.3, Itasca Consulting Group Inc., Minneapolis, Minn, USA, 1995.

[28] P. G. van Duijnen and E. A. Kwast, "3D modeling of a piled embankment on soft soil," in Proceedings of the International Workshop on Geotechnics of Soft Soils, pp. 589-594, Noordwijkerhout, The Netherlands, 2003.

[29] Y. Laurent, B. Simon, D. Dias, and R. Kastner, "A 3D finite difference analysis of embankments over pile reinforced soft soil," in Proceedings of the International Workshop on Geotechnics of Soft Soils, pp. 271-276, Noordwijkerhoud, The Netherlands, 2003.

[30] G. S. Fahmi Farag, Lateral spreading in basal reinforced embankments supported by pile like elements, M.S. thesis, Universitat Kassel, 2008.

[31] S. Satibi, Numerical analysis and design criteria of embankments on floating piles, Ph.D. thesis, Universität Stuttgart, Stuttgart, Germany, 2009. 
[32] H. Slaats, Load transfer platform, bending moments in slender piles, M.S. thesis, Technical University Delft, 2008.

[33] S. Kalla, Modeling studies to assess long term settlement of light weight aggregate embankment, M.S. thesis, University of Texas at Arlington, 2010.

[34] P. J. Naughton and G. T. Kempton, "Comparison of analytical and numerical analysis design methods for piled embankments," in Proceedings of the Geo-Frontiers, pp. 487-496, Austin, Tex, USA, January 2005.

[35] K. Terzaghi, Theoretical Soil Mechanics, Wiley, New York, NY, USA, 1943.

[36] J. W. McNulty, "An Experimental study of arching in sand," Tech. Rep. I-674, U.S. Army Engineer Waterways Experiment Station, Corps of Engineers, Vicksburg, Mississippi, 1965.

[37] J. Han and M. H. Wayne, "Pile-soil-interactions in geosynthetic reinforced platform/piled embankments over soft soil," Tech. Rep. 000777, Presentation and CD-Print at 79th Annual Transportation Research Board Meeting, Washington, DC, USA, 2000.

[38] J. M. Duncan and C. Y. Chang, "Nonlinear analysis of stress and strain in soils," Journal of the Soil Mechanics and Foundations Division, vol. 96, no. 5, pp. 1629-1652, 1970.

[39] T. Schanz, P. A. Vermeer, and P. G. Bonnier, "The hardening soil model: formulation and verification," in Beyond 2000 in Computational Geotechnics-10 Years of Plaxis, Balkema, pp. 281-296, Rotterdam, The Netherlands, 1999.

[40] R. B. J. Brinkgreve and P. A. Vermeer, Plaxis Finite Element Code for Soil and Rock Analysis-Version 7, Balkema, Rotterdam, 1997.

[41] K. S. Ti, B. B. K. Huat, J. Noorzaei, M. S. Jaafar, and G. S. Sew, "Review of basic soil constitutive models for geotechnical application," Electronic Journal of Geotechnical Engineering, vol. 16, pp. 1-18, 2009.

[42] P. J. Naughton, "The significance of critical height in the design of piled embankments," in Proceedings of the 9th GeoDenver, pp. 18-21, Denver, Colorado, February 2007. 

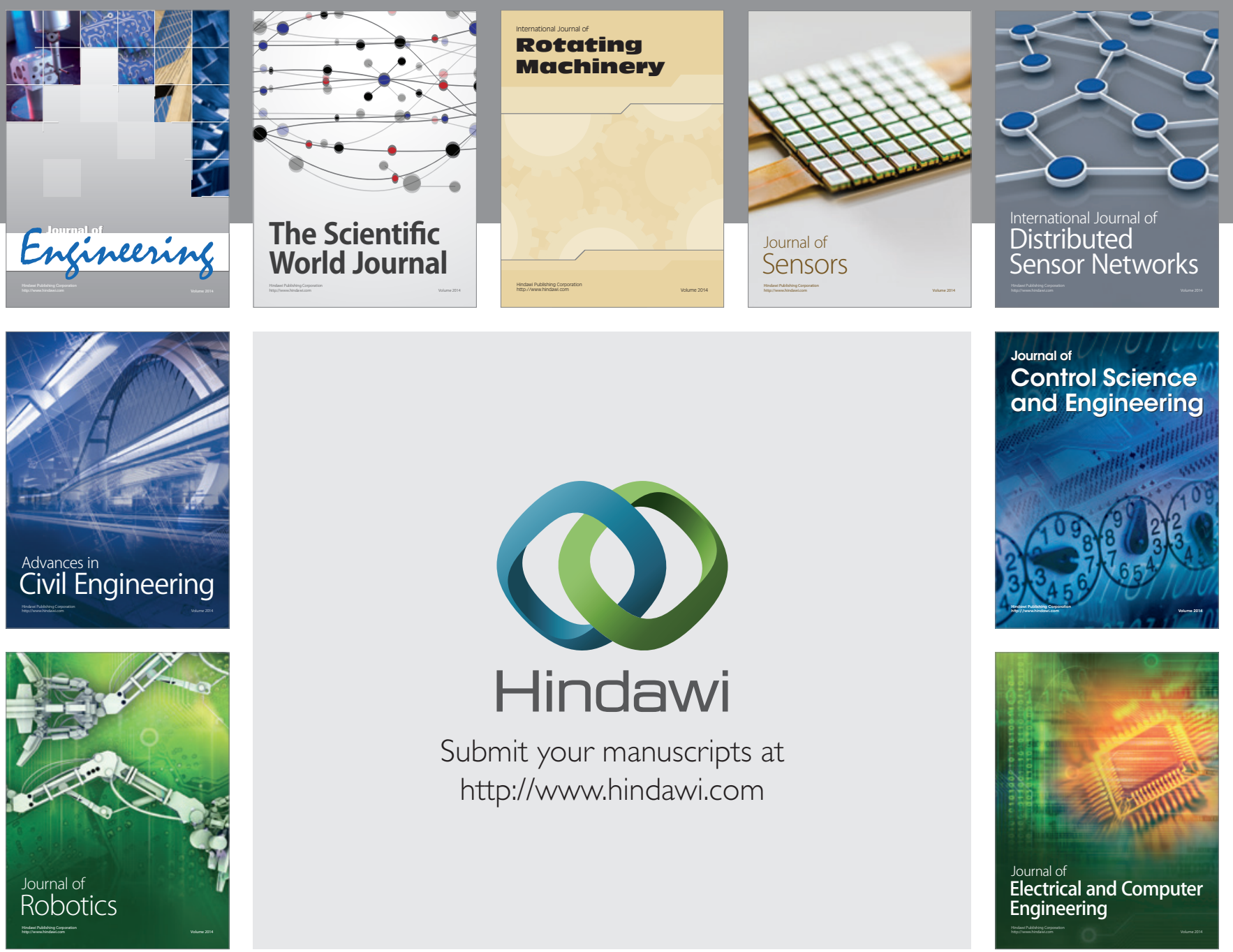

Submit your manuscripts at

http://www.hindawi.com
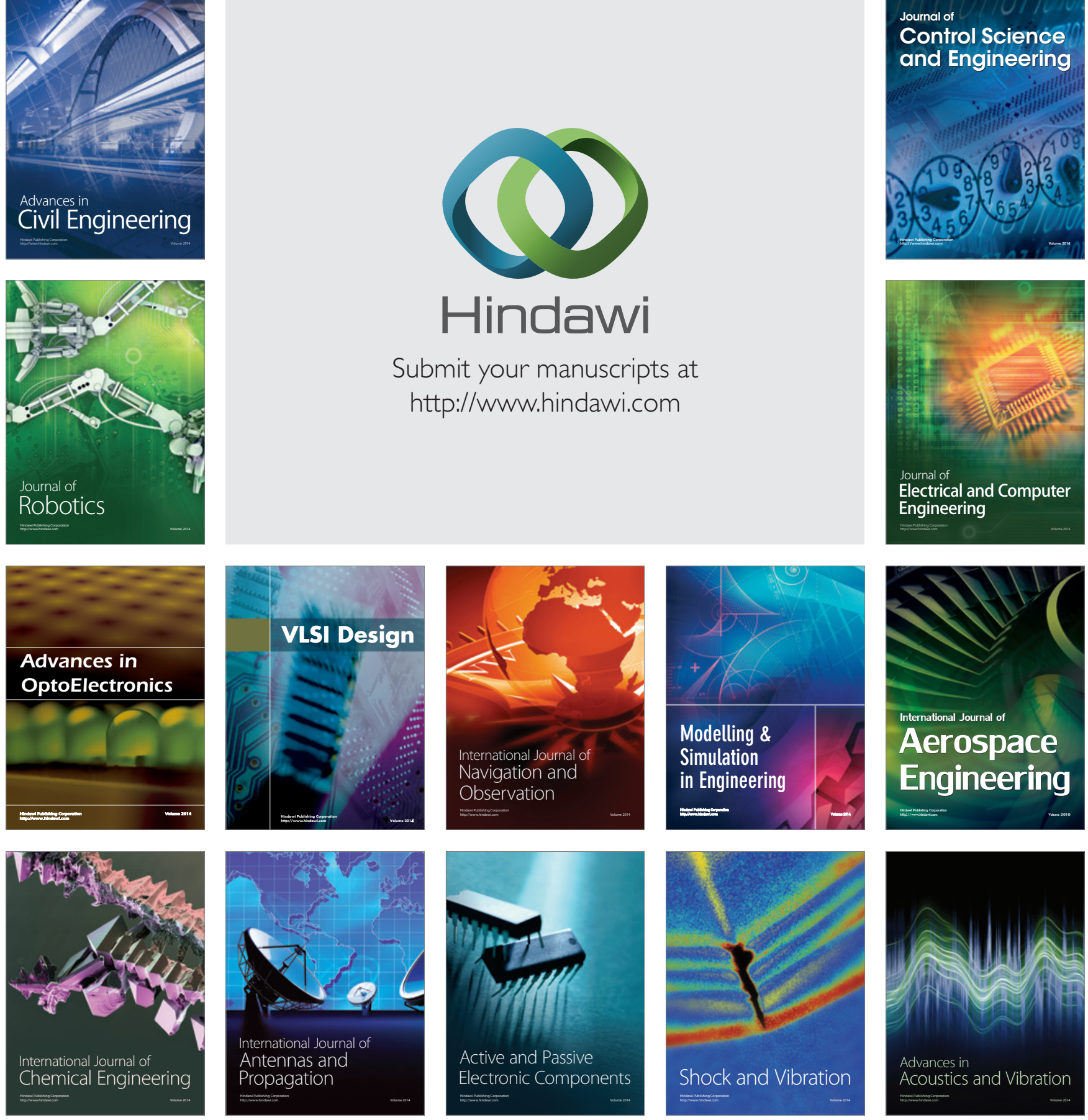